Article

\title{
Ni-Mg-Al solid basic layered double oxide catalysts prepared using surfactant-assisted coprecipitation method for $\mathrm{CO}_{2}$ reforming of $\mathrm{CH}_{4}$
}

\author{
Pengjia Tan a,b, Zhihua Gao a,\#, Chaofeng Shen c, Yali Du a, Xiaodong Li a, Wei Huang a,* \\ a Key Laboratory of Coal Science and Technology, Ministry of Education of China and Shanxi Province, Taiyuan University of Technology, Taiyuan 030024, \\ Shanxi, China \\ b The 389 Plant of the Sixth Academy of China Aerospace Science \& Industry Corporation, Hohhot 010010, Inner Mongolia, China \\ ${ }^{c}$ Huadian Electric Power Research Institute, Hangzhou 310027, Zhejiang, China
}

\section{A R T I C L E I N F O}

Article history:

Received 27 April 2014

Accepted 1 July 2014

Published 20 December 2014

\section{Keywords:}

Surfactant

Coprecipitation method

Nickel

Magnesium aluminum oxide

Methane

Carbon dioxide

Reforming

\begin{abstract}
A B S T R A C T
$\mathrm{Ni}-\mathrm{Mg}$-Al solid basic catalysts for $\mathrm{CO}_{2}$ reforming of $\mathrm{CH}_{4}$ were prepared using a surfactant-assisted coprecipitation method. The preferred orientations of the surfactants on the $\mathrm{Ni}(111)$ and $\mathrm{Ni}(200)$ crystal planes were investigated. The catalytic performance of the surfactant-modified catalysts was tested at $800{ }^{\circ} \mathrm{C}$. The cetyltrimethylammonium bromide (CTAB)-modified catalyst (CB-LDO; LDO = layered double oxide) was further studied at various reaction temperatures. All the catalysts were characterized using Fourier-transform infrared spectroscopy, X-ray diffraction, temperature-programmed reduction, X-ray photoelectron spectroscopy, high-resolution transmission electron microscopy, and temperature-programmed oxidation. The results show that growth of the $\mathrm{Ni}(200)$ plane is promoted by tetrapropylammonium hydroxide and restrained by P123, PVP, and CTAB. The crystallinity degree of $\mathrm{Ni}(200)$ plays a key role in the activation of $\mathrm{CH}_{4}$. The CB-LDO catalysts retain high activities and stabilities, because of the crystal phase transformation at high temperature during the reaction; this leads to the formation of spinel $\mathrm{NiAl}_{2} \mathrm{O}_{4}$ and exposure of the $\mathrm{Ni}(200)$ crystal plane.
\end{abstract}

(C) 2014, Dalian Institute of Chemical Physics, Chinese Academy of Sciences. Published by Elsevier B.V. All rights reserved.

\section{Introduction}

The chief sources of $\mathrm{CH}_{4}$ are natural gas, coal-bed gas, shale gas, and biogas. $\mathrm{CO}_{2}$ is the main emission in the conversion and use of fossil fuels, and is also the major component of steel blast-furnace gas, converter gas, and furnace gas. There are large natural reserves of $\mathrm{CH}_{4}$, and $\mathrm{CO}_{2}$ is an inevitable product of fossil fuel use. $\mathrm{CO}_{2}$ reforming of $\mathrm{CH}_{4}\left(\mathrm{CO}_{2}+\mathrm{CH}_{4} \rightarrow 2 \mathrm{CO}+2 \mathrm{H}_{2}\right.$, $\Delta H^{\Theta_{298 \mathrm{~K}}}=247 \mathrm{~kJ} / \mathrm{mol}$ ) is a potential efficient process for the preparation of synthesis gas (syngas), which is the most important step in $\mathrm{CH}_{4}$ comprehensive use and $\mathrm{CO}_{2}$ emission re- duction. Recently, research on the development of catalysts for $\mathrm{CH}_{4}-\mathrm{CO}_{2}$ reforming has focused on identifying catalysts with higher activities and better stabilities for industrial applications. The transition elements in group VIII and noble metals such as $\mathrm{Ru}, \mathrm{Rh}, \mathrm{Pt}$, and Ir are the most common active components used for catalytic reforming of $\mathrm{CH}_{4}$ with $\mathrm{CO}_{2}$. Although noble metal catalysts have high activities and are less sensitive to carbon deposition, their industrial applications are restricted by their high costs. Ni-based catalysts have been identified as promising catalysts for $\mathrm{CO}_{2}$ reforming of $\mathrm{CH}_{4}$, because of their high catalytic activities and low costs [1].

\footnotetext{
* Corresponding author. Tel/Fax: +86-351-6018073; E-mail: huangwei@tyut.edu.cn

\# Corresponding author. Tel/Fax: +86-351-6018466; E-mail: gaozhihua@tyut.edu.cn

This work was supported by the National High Technology Research and Development Program of China (863 Program, 2013AA051201).

DOI: 10.1016/S1872-2067(14)60171-6 | http://www.sciencedirect.com/science/journal/18722067 | Chin. J. Catal., Vol. 35, No. 12, December 2014
} 
Ni-Mg-Al-LDHs (LDH: layered double hydroxide) are a series of supramolecular materials formed by anion-cation intercalation assembly. Calcination of these materials results in the formation of solid basic layered double oxide (LDO) catalysts that exhibit excellent catalytic performances in $\mathrm{CO}_{2}$ reforming of $\mathrm{CH}_{4}$, because of their mesoporous structures. $\mathrm{Xu}$ et al. [2] used the surfactant $(\mathrm{EO})_{20}(\mathrm{PO})_{70}(\mathrm{EO})_{20}$ triblock copolymer (P123) as a soft template for evaporation-induced self-assembly to prepare a $\mathrm{Ni}-\mathrm{Mg}-\mathrm{Al}(\mathrm{O})$ catalyst with a mesoporous structure for $\mathrm{CO}_{2}$ reforming of $\mathrm{CH}_{4}$ at $700{ }^{\circ} \mathrm{C}[\mathrm{GHSV}=15000$ $\left.\mathrm{mL} /\left(\mathrm{h} \cdot \mathrm{g}_{\text {cat }}\right), V\left(\mathrm{CH}_{4}\right) / V\left(\mathrm{CO}_{2}\right)=1 / 1\right]$. The catalyst was highly active and $\mathrm{CH}_{4}$ conversion remained at $80 \%$ after reaction for 100 h. Zhang et al. [3] carried out dry reforming of $\mathrm{CH}_{4}$ over a Ni-Mg-Al-LDHs catalyst. The catalyst was not deactivated after $160 \mathrm{~h}$. In our previous work [4], we showed that Ni-Mg-Al-LDO catalysts derived from Ni-Mg-Al hydrotalcite had catalytic stability over a period of $2000 \mathrm{~h}$ on stream at GHSV $=8000$ $\mathrm{mL} /\left(\mathrm{h} \cdot \mathrm{g}_{\text {cat }}\right)$ and $V\left(\mathrm{CH}_{4}\right) / V\left(\mathrm{CO}_{2}\right)=1 / 1$. The conversions of $\mathrm{CH}_{4}$ and $\mathrm{CO}_{2}$ remained over $95 \%$ after reaction for $2000 \mathrm{~h}$.

The morphology, particle size, and some properties of hydrotalcite can be modified using surfactants [5]; this has the following advantages. (1) It overcomes the drawbacks caused by metal particle aggregation caused by high local concentrations when a precipitating agent is added to a solution. (2) It can also significantly improve metal dispersion and optimize the textural properties of the catalyst [6]. (3) Regulation of the intrinsic kinetics [7,8] and mitigation of carbon deposition [9] can be achieved by controlling the crystal planes exposed and preparing structures with surface defects. In this study, we prepared Ni-Mg-Al-LDO catalysts using a surfactant-assisted coprecipitation method, and evaluated their catalytic performances in $\mathrm{CH}_{4}$ reforming of $\mathrm{CO}_{2}$. The microscopic effects of surfactants on the Ni-Mg-Al hydrotalcite precursors and on the crystal structure, physicochemical properties, and exposure of different crystal planes of the Ni complex oxide were examined. The relationship between catalyst structure and its catalytic properties was explored.

\section{Experimental}

\subsection{Catalyst preparation}

$\mathrm{Ni}-\mathrm{Mg}$-Al solid basic catalysts were prepared using a surfactant-assisted coprecipitation method. A certain amount of $\mathrm{Na}_{2} \mathrm{CO}_{3}$ was dissolved into $100 \mathrm{~mL}$ deionized water, a surfactant was dissolved into another $50 \mathrm{~mL}$ deionized water, then added these two solutions into four flask respectively. A nitrate solution [120 $\mathrm{mL}, n(\mathrm{Ni}+\mathrm{Mg}) / n(\mathrm{Al})=3]$ was added dropwise to aqueous solutions of $\mathrm{Na}_{2} \mathrm{CO}_{3}\left(n\left(\mathrm{CO}_{3}{ }^{2-}\right) / n\left(\mathrm{M}^{n+}\right)=2 / 3\right)$ containing either tetrapropylammonium hydroxide (TPAOH), P123, poly(vinylpyrrolidone) (PVP), cetyltrimethylammonium bromide (CTAB), or no surfactant, at $60{ }^{\circ} \mathrm{C}$. Coprecipitation was performed under constant agitation at $60{ }^{\circ} \mathrm{C}$; the $\mathrm{pH}$ was kept at 9.15 by adding $1 \mathrm{~mol} / \mathrm{L} \mathrm{NaOH}$ solution. The resulting suspension was stirred vigorously at $60^{\circ} \mathrm{C}$ for $3 \mathrm{~h}$. The final slurry mixture was transferred to a Teflon bottle and crystallized at $80{ }^{\circ} \mathrm{C}$ for $24 \mathrm{~h}$. After aging, the precipitate, which was light green, was removed from the supernatant and rinsed several times with deionized water until the $\mathrm{pH}$ was 7 . The aged slurry was removed by filtration and dried in an oven at $80{ }^{\circ} \mathrm{C}$ overnight. A light-green solid was obtained after calcination of the final filter cake by slowly increasing the temperature $\left(5^{\circ} \mathrm{C} / \mathrm{min}\right.$ ramping rate) to $700{ }^{\circ} \mathrm{C}$ and maintaining the final temperature for $6 \mathrm{~h}$. It is stressed that the mass fraction of $\mathrm{NiO}$ in the catalyst was controlled to $10 \%$. The catalysts are denoted by TH-LDO, P3-LDO, PP-LDO, CB-LDO, and LDO.

\subsection{Catalyst characterization}

The functional groups of the catalyst precursor were identified by Fourier-transform infrared (FT-IR) spectroscopy (Bruker Vertex 70) using $\mathrm{KBr}$ pellets in the range 4000-400 $\mathrm{cm}^{-1}$ at a resolution of $4 \mathrm{~cm}^{-1}$.

The catalyst textures were investigated using the standard BET and BJH methods to calculate the specific surface areas and pore size distributions, using a Micromeritics ASAP 2020 system.

The crystalline phases of the catalysts were identified by X-ray diffraction (XRD), using a DX-2700 X-ray powder diffractometer with $\mathrm{Cu} K_{\alpha}$ radiation $(\lambda=1.5405 \AA, 40 \mathrm{kV}, 30 \mathrm{~mA})$ in steps of $0.01^{\circ}$ at a scanning rate of $8^{\circ} / \mathrm{min}$ from $5^{\circ}$ to $85^{\circ}$ under atmospheric pressure. The grain size of the catalysts were obtained using Scherrer's equation.

The dispersed state and morphology of the active metal were probed using high-resolution transmission electron microscopy (HRTEM; FEITECNAI G²F-20).

The active $\mathrm{Ni}$ valence states and electron binding energies $\left(E_{\mathrm{b}}\right)$ of the catalysts were studied by X-ray photoelectron spectroscopy (XPS, Thermo Fisher), using an Escalab 250 scanning microprobe instrument with $\mathrm{Al} K_{\alpha}$ radiation $(30 \mathrm{kV}, h v=1486.6$ $\mathrm{eV})$ in steps of $0.1 \mathrm{eV}$ under ultrahigh vacuum $\left(2.0 \times 10^{-7} \mathrm{~Pa}\right)$, calibrated internally using the carbon deposit C $1 s\left(E_{\mathrm{b}}=284.6\right.$ $\mathrm{eV}$ ). Background was subtracted using Sheirly method.

The reductive properties of the catalysts were investigated by temperature-programmed reduction (TPR), using a TP-5000 (Xianquan China) instrument equipped with a thermal conductivity detector to establish the appropriate reduction temperature or measure the hydrogen consumption. The tests were performed using a quartz reactor containing the catalyst (50 mg) in $5 \% \mathrm{H}_{2}$ (balanced with $\mathrm{N}_{2} 20 \mathrm{~mL} / \mathrm{min}$ ) and a heating rate of $10^{\circ} \mathrm{C} / \mathrm{min}$, from room temperature to $900^{\circ} \mathrm{C}$.

The oxidation properties of carbon deposited on the used catalysts were investigated by temperature-programmed oxidation-mass spectrometry $\left(\mathrm{O}_{2}\right.$-TPO-MS), using a QIC-20 analytical instrument (HIDEN). The used catalyst (100 mg) was pretreated at $150{ }^{\circ} \mathrm{C}$ for $30 \mathrm{~min}$ in a He atmosphere, cooled to $50{ }^{\circ} \mathrm{C}$, and then the atmosphere was switched to $5 \% \mathrm{O}_{2}(20$ $\mathrm{mL} / \mathrm{min}$, Ar balance). The temperature was increased linearly to $900{ }^{\circ} \mathrm{C}$ at $10{ }^{\circ} \mathrm{C} / \mathrm{min} . \mathrm{CO}_{2}(\mathrm{~m} / \mathrm{z}=44)$ in the effluent was detected using a mass spectrometer (QIC-20, HIDEN) and recorded as a function of temperature, which can determine the type of carbon species. The amount of carbon deposition of used catalysts was calculated by oxidation of the charcoal activated power as the standard. 


\subsection{Catalyst evaluation}

The catalytic performances were evaluated using a fixedbed quartz reactor of inner diameter $8 \mathrm{~mm}$ under atmospheric pressure. The catalyst (0.30 g, 40-60 mesh), diluted with quartz sand (1.70 g), was loaded into the reactor. A thermocouple was placed in the catalyst bed to monitor the reaction temperature. Prior to the reactions, the catalysts were reduced at $800{ }^{\circ} \mathrm{C}$ for $2 \mathrm{~h}$ in a flow of mixed gases $\left[V\left(\mathrm{H}_{2}\right) / V\left(\mathrm{~N}_{2}\right)=1: 1\right]$. The molar ratio of $\mathrm{CH}_{4}$ to $\mathrm{CO}_{2}$ was $1: 1$ at a GHSV of 60000 $\mathrm{mL} /\left(\mathrm{h} \cdot \mathrm{g}_{\text {cat }}\right)$. The product gas was analyzed using a gas chromatograph (Haixin GC-950) on packed column (TDX-01 type, $\mathrm{Ar}$ as carrier gas) equipped with a thermal conductivity detector after passing a cold trap.

\section{Results and discussion}

\subsection{Catalytic performance}

The stability of the LDO catalyst prepared using coprecipitation without surfactant assistance in our previous work [4] was investigated at $\mathrm{GHSV}=8000 \mathrm{~mL} /\left(\mathrm{h} \cdot \mathrm{g}_{\text {cat }}\right)\left[V\left(\mathrm{CH}_{4}\right) / V\left(\mathrm{CO}_{2}\right)=1: 1\right]$ at $800{ }^{\circ} \mathrm{C}$. The conversions of $\mathrm{CH}_{4}$ and $\mathrm{CO}_{2}$ were stable, over $95 \%$, after reaction for $2000 \mathrm{~h}$. In this work, the GHSV was increased to $60000 \mathrm{~mL} /\left(\mathrm{h} \cdot \mathrm{g}_{\text {cat }}\right)\left(\mathrm{CH}_{4} / \mathrm{CO}_{2}=1: 1\right)$ to accelerate catalyst deactivation, thereby shortening the evaluation time and increasing the catalyst screening speed. The catalytic activities with time on stream are shown in Fig. 1. The results show that the surfactant significantly affects the catalytic activity. A comparison with the LDO catalyst without a surfactant shows that TPAOH clearly promotes the reaction, and the initial conversions of $\mathrm{CH}_{4}$ and $\mathrm{CO}_{2}$ over TH-LDO are above 95\%. However, additions of P123, PVP, and CTAB surfactants have an inhibitory effect. It is worth noting that the initial $\mathrm{CH}_{4}$ conversion over PP-LDO is only $18 \%$, and that over CB-LDO is nearly zero. However, the $\mathrm{CH}_{4}$ and $\mathrm{CO}_{2}$ conversions over CB-LDO quickly reach their peaks in a few hours. These results show that the initial activities of the catalysts synthesized by different surfactant-assisted methods vary greatly, which suggests that the surfactants significantly affect the structures and surface states of the fresh catalysts.

\subsection{Analysis of catalytic activity}

The XRD patterns of the uncalcined catalysts are shown in Fig. 2(a). It can be seen that no peaks for oxide or hydroxide crystalline phases are present, only the characteristic LDH reflections of the (003), (006), (009), (015), (018), (110), and (113) planes, indicating that the precursors are pure LDH phases. In the precursor patterns, the sharp characteristic peaks of the (003) plane of the hydrotalcite-like LDH phase, which determines the interlamellar spacing, are strong [10] and symmetric. In addition, the (110) and (113) crystal plane diffraction peaks are clearly distinguishable. These results suggest that the synthetic Ni-Mg-Al-LDHs are hexagonal structures with high crystallinities, and confirm that the surfactant-assisted coprecipitation method gives perfect Ni-Mg-Al-LDHs. The lattice parameters, including $a\left[a=2 d_{(003)}\right]$ and $c\left[c=d_{(003)}+2 d_{(006)}+3 d_{(009)}\right]$, calculated using the Scherrer equation, are listed in Table 1 . The value of $a$ is the average semi-diameter of the metal cations in the interlayer structure, and $c$ is closely related to the distance, charge density, anion size, and amount of water molecules in the interlayer structure [11]. The data show that adding TPAOH, PVP, or CTAB decreased $c$, indicating an increase in the positive charge density in the laminates and enhancement of the coulombic forces of laminates and anions between the layers. However, adding P123 increased $c$, which indicates a decrease in positive charge density in the laminates and a decrease in the coulombic forces of laminates and anions between layers. The reason is that TPAOH and CTAB are quaternary ammonium salts, and the $\mathrm{N}$ atom is connected to a carbonyl in PVP. The $\mathrm{N}$ atoms in these three compounds are therefore electron deficient, which increases the coulombic forces of laminates and anions between layers. P123 is electrically neutral, with no electron-deficient center and lone pair electrons on the oxygen, which leads to an electron cloud of high density; this decreases the density of positive charges on laminates and the coulombic forces of lam-
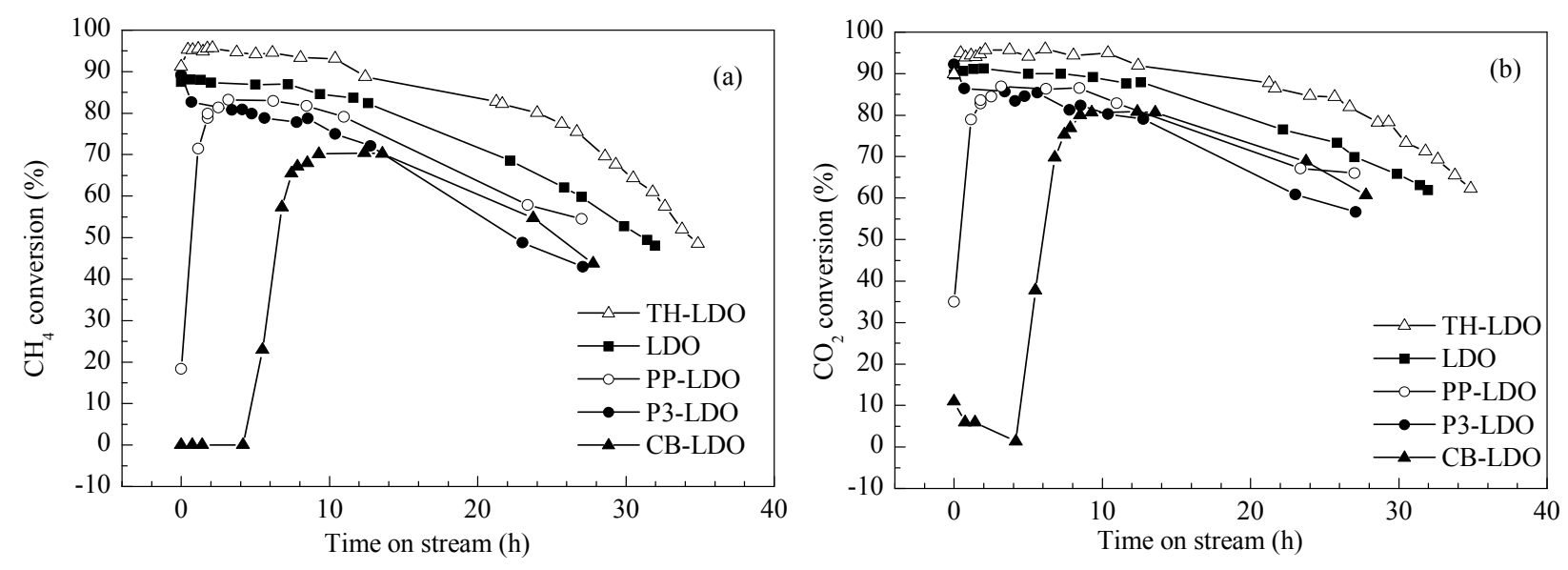

Fig. 1. $\mathrm{CH}_{4}$ (a) and $\mathrm{CO}_{2}$ (b) conversions over catalysts with time on stream at $800{ }^{\circ} \mathrm{C}$. Reaction conditions: $\mathrm{CH}_{4} / \mathrm{CO}_{2}=1 / 1, p=0.1 \mathrm{MPa}, \mathrm{GHSV}=60000$ $\mathrm{mL} /$ (h.gcat). 

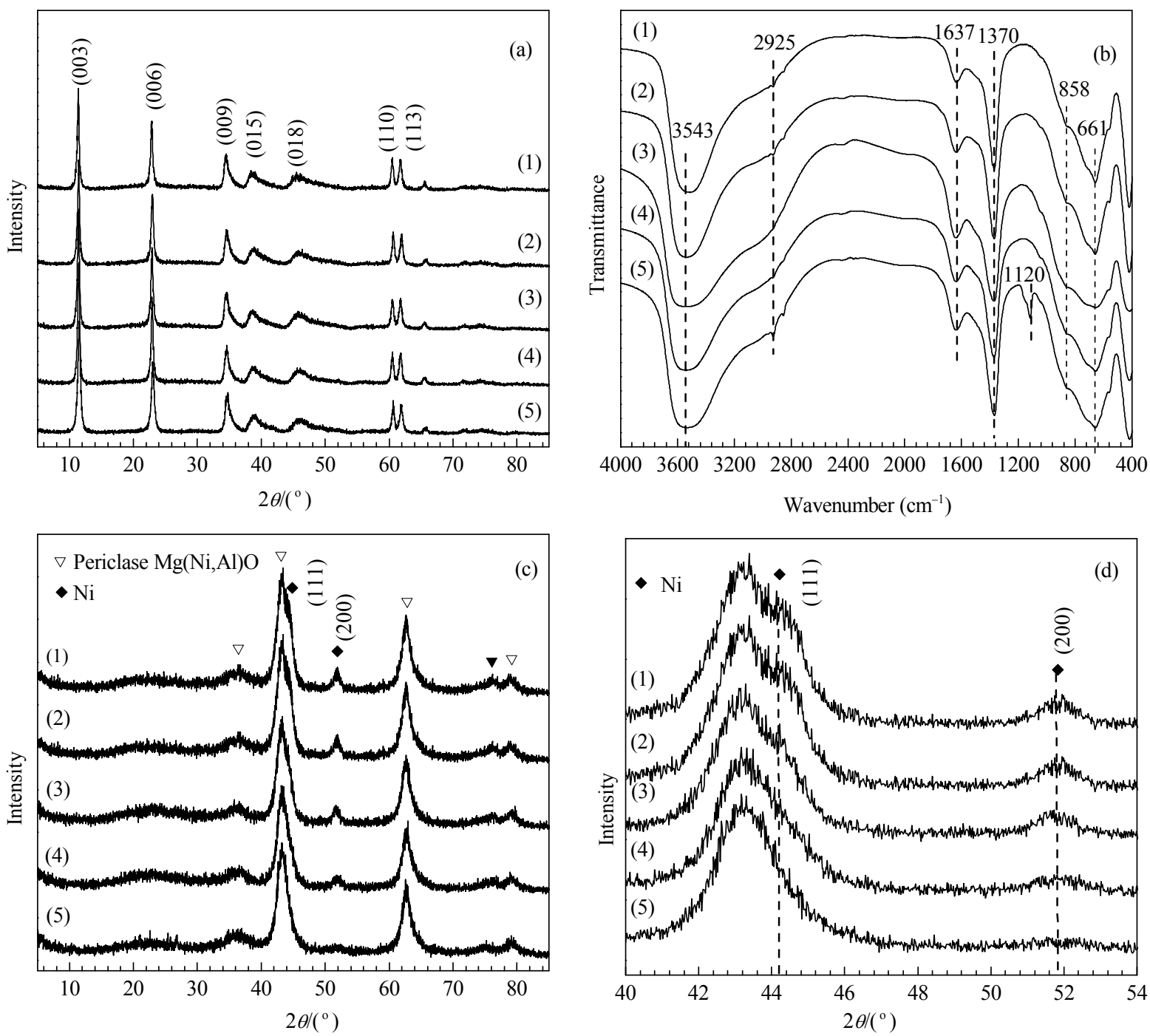

Fig. 2. XRD patterns (a) and FT-IR spectra (b) of catalysts before calcination; XRD patterns of catalysts after calcination and reduction (c, d). (1) TH-LDO; (2) LDO; (3) P3-LDO; (4) PP-LDO; (5) CB-LDO.

inates and anions between layers. These results, combined with the catalytic performances shown in Fig. 1, show that electropositive surfactants enhance the coulombic forces of laminates and anions between layers. This is the main reason for the clear promotion of catalytic activity.

The FT-IR spectra of the LDH precursors are presented in Fig. 2(b). All the samples show broad bands at $3543 \mathrm{~cm}^{-1}$, from the stretching mode of structural - $\mathrm{OH}$ groups in the metal hydroxide layer. A small shoulder at $2925 \mathrm{~cm}^{-1}$ is ascribed to a second type of $-\mathrm{OH}$ stretching vibration, arising from interlayer hydrogen bonding with carbonate groups. A weak sharp band

Table 1

Structure of different precursors.

\begin{tabular}{lcccccc}
\hline Sample & $\begin{array}{c}d_{(003)} \\
(\mathrm{nm})\end{array}$ & $\begin{array}{c}d_{(006)} \\
(\mathrm{nm})\end{array}$ & $\begin{array}{c}d_{(009)} \\
(\mathrm{nm})\end{array}$ & $\begin{array}{c}d_{(110)} \\
(\mathrm{nm})\end{array}$ & $\begin{array}{c}a \\
(\mathrm{~nm})\end{array}$ & $\begin{array}{c}c \\
(\mathrm{~nm})\end{array}$ \\
\hline TH-LDH & 7.715 & 3.860 & 2.582 & 1.525 & 3.050 & 23.181 \\
LDH & 7.715 & 3.867 & 2.598 & 1.526 & 3.052 & 23.243 \\
P3-LDH & 7.776 & 3.880 & 2.589 & 1.526 & 3.052 & 23.303 \\
PP-LDH & 7.716 & 3.870 & 2.582 & 1.526 & 3.052 & 23.202 \\
CB-LDH & 7.687 & 3.857 & 2.587 & 1.523 & 3.052 & 23.162 \\
\hline
\end{tabular}

at $1120 \mathrm{~cm}^{-1}$ shows the presence of $\mathrm{C}-\mathrm{N}$ single bonds [12]. The strong band at $1370 \mathrm{~cm}^{-1}$ and weak band at $858 \mathrm{~cm}^{-1}$ are attributed to the stretching vibration and out-of-plane bending vibration of $\mathrm{CO}_{3}{ }^{2-}$, respectively. The weak band at $1637 \mathrm{~cm}^{-1}$ is ascribed to the bending vibration [deformation mode of $\mathrm{H}-\mathrm{O}-\mathrm{H}$ $(\delta \mathrm{H}-\mathrm{O}-\mathrm{H})]$ of interlayer water molecules in the LDH. The bands in the range $500-750 \mathrm{~cm}^{-1}$ are typical of the frameworks of LDH materials, and indicate $\mathrm{M}-\mathrm{O}-\mathrm{M}$ stretching $(\mathrm{M}=\mathrm{Mg}$, Ni, and Al) [13]; this further confirms that the precursors are ordered LDHs.

The XRD patterns of the Ni-Mg-Al-LDO catalysts after calcination and reduction are shown in Fig. 2(c). All the catalysts exhibit the characteristic peaks of $\mathrm{Mg}(\mathrm{Ni}, \mathrm{Al}) \mathrm{O}$ periclase at $2 \theta=$ $36.4^{\circ}, 43.4^{\circ}, 62.9^{\circ}$, and $79.2^{\circ}$ [14]. The peaks observed at $2 \theta=$ $44.5^{\circ}, 51.8^{\circ}$, and $76.3^{\circ}$ are assigned to the Ni(111), (200), and (220) planes, respectively. It can be clearly seen from Fig. 2(c) that the crystallinities indicated by the $\mathrm{Ni}(111)$ and $\mathrm{Ni}(200)$ reflections vary, and the intensities of the $\mathrm{Ni}(200)$ reflections increase significantly in the order CB-LDO, PP-LDO, P3-LDO, LDO, and TH-LDO. To avoid measurement errors caused by 
different frequencies, the shoulder reflection of the $\mathrm{Ni}(111)$ plane at $2 \theta=44.5^{\circ}$ is used as the primary standard for the measurements, and the relative intensity of the $\mathrm{Ni}(200)$ reflec-

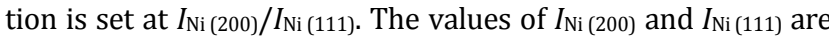
estimated, using the Scherrer equation, from the full-widths at half-maximum of the peaks at $2 \theta=51.8^{\circ}$ and $44.5^{\circ}$, respectively. It can be seen that the order of the calculated $I_{\mathrm{Ni}(200)} / I_{\mathrm{Ni}(111)}$ values of the catalysts is TH-LDO $(27.7 \%)>\operatorname{LDO}(25.4 \%)>$ P3-LDO $(22.0 \%)>$ PP-LDO $(14.3 \%)>$ CB-LDO (11.1\%); this agrees with the initial conversions of $\mathrm{CH}_{4}$ and $\mathrm{CO}_{2}$ in Fig. 1. These results indicate that the $\mathrm{Ni}(200)$ plane significantly affects the catalytic activity. The degree of exposure of the $\mathrm{Ni}(200)$ crystal plane differs among the catalysts, and can be traced to the adsorptive capacity of the surfactant on the crystal plane. The surfactants are directionally adsorbed on different planes, and this affects the surface free energies of crystals and the crystal plane growth rate, resulting in modification of the metal particle size and morphology [15].

Figure 3 shows the HRTEM images of catalysts after calcination and reduction. The $d$ values of the two main exposed crystal planes are 0.203 and $0.176 \mathrm{~nm}$, respectively. A combination of these results and the corresponding fast Fourier-transform images enables identification of $\mathrm{Ni}(111)$ and $\mathrm{Ni}(200)[16,17]$. However, the absence of $\mathrm{Ni}(200)$ in the CB-LDO sample (Fig. $3(\mathrm{e})$ ) indicates that the crystalline form was transformed and grew a second time, but the growth of the crystal plane protected by a surfactant was restrained.

The crystalline structure of $\mathrm{Ni}$ is face-centered cubic (fcc). Because of the symmetry features of the fcc structure, the lat- eral faces can alternate between the $\mathrm{Ni}(100)$ and $\mathrm{Ni}(111)$ crystal planes. $\mathrm{Ni}(200)$ is the second-order diffraction of $\mathrm{Ni}(100)$ in the cell structure, (200) is the interference index, and (100) is the crystal plane index; their contributions to the space lattice are the same, despite their different definitions. $\mathrm{Ni}(200)$ in the XRD patterns is therefore equal to $\mathrm{Ni}(100)$ in the space lattice. The high energy of the average band $d$ is not beneficial to $\mathrm{CH}_{x}$ decomposition, so $\mathrm{Ni}(100)$ could decrease the activation energy barrier and promote the decomposition of $\mathrm{CH}_{x}$ [18]. $\mathrm{Ni}(100)$ [i.e., $\mathrm{Ni}(200)$ ] rather than $\mathrm{Ni}(111)$ is the main adsorption surface when $\mathrm{CH}_{4}$ decomposes [19]; this could explain the relationship between the relative intensity of $\mathrm{Ni}(200)$ and the activity.

The $\mathrm{H}_{2}$-TPR profiles of the catalysts after calcination are shown in Fig. 4. The peak temperatures range from 370 to 866 ${ }^{\circ} \mathrm{C}$, suggesting various types of interaction between $\mathrm{NiO}$ species and the mesoporous skeleton of the Ni-Mg-Al-LDO sample. According to literature reports, the reduction peaks from 370 to $450{ }^{\circ} \mathrm{C}$ can be attributed to the reduction of pure $\mathrm{NiO}[20,21]$, and the reduction peaks from 500 to $800{ }^{\circ} \mathrm{C}$ are associated with weak interactions between $\mathrm{Ni}^{2+}$ and $\mathrm{Al}_{2} \mathrm{O}_{3}$ or $\mathrm{MgO}[22,23]$. The peak above $800{ }^{\circ} \mathrm{C}$ is attributed to the reduction of $\mathrm{Ni}^{2+}$ in a $\mathrm{Ni}-\mathrm{Mg}$ solid solution or Ni-Al spinel $[24,25]$. The order of the high reduction peak temperatures, i.e., TH-LDO $\left(866^{\circ} \mathrm{C}\right)>$ LDO $\left(840{ }^{\circ} \mathrm{C}\right)>$ P3-LDO $\left(817^{\circ} \mathrm{C}\right)>$ PP-LDO $\left(787^{\circ} \mathrm{C}\right)>$ CB-LDO $(702$ $\left.{ }^{\circ} \mathrm{C}\right)$, is in accordance with the order of the initial activities. This indicates that strong interactions between $\mathrm{Ni}$ particles and the support provide the main catalytically active sites. It has been reported that strong metal-support interactions (SMSIs) form
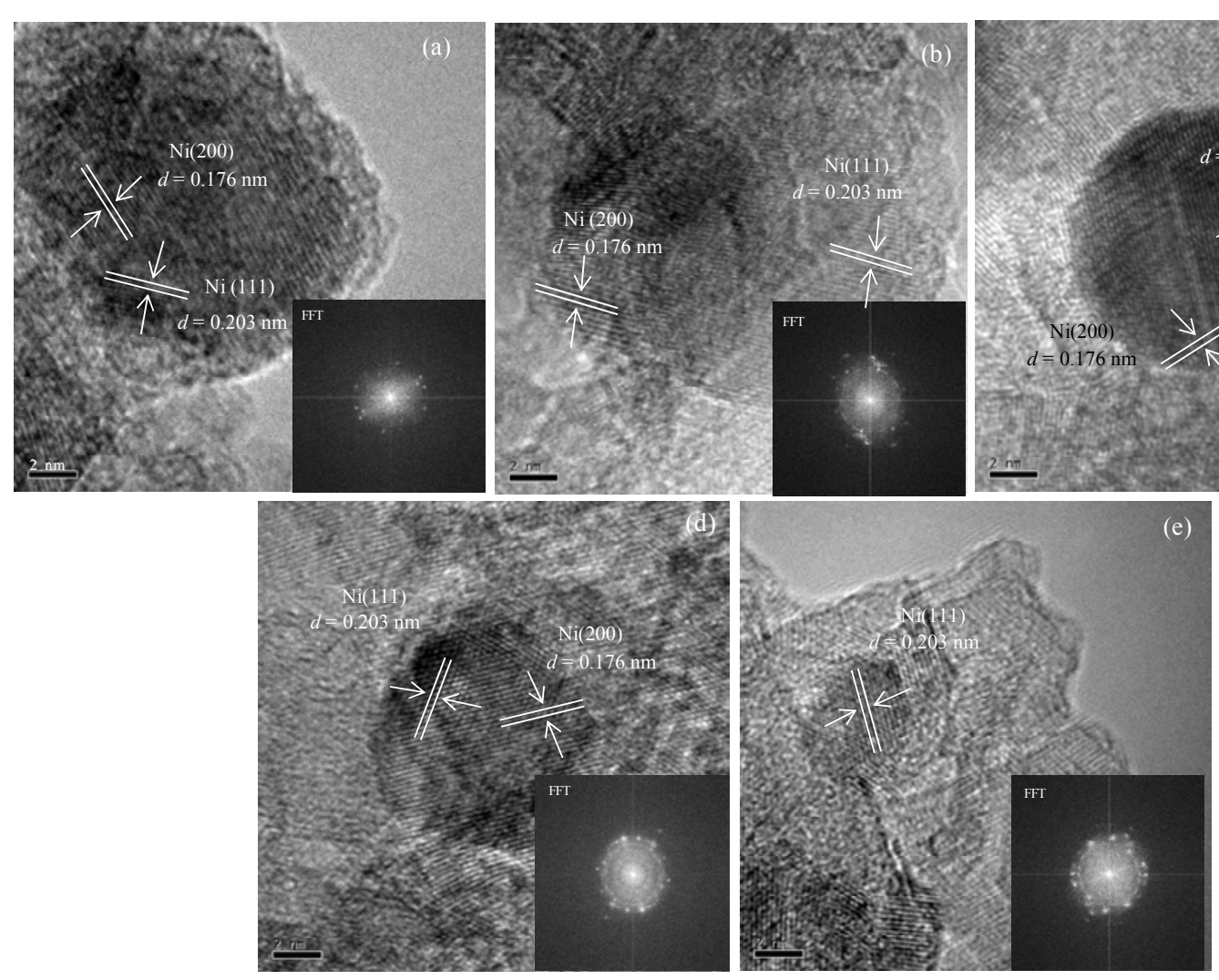

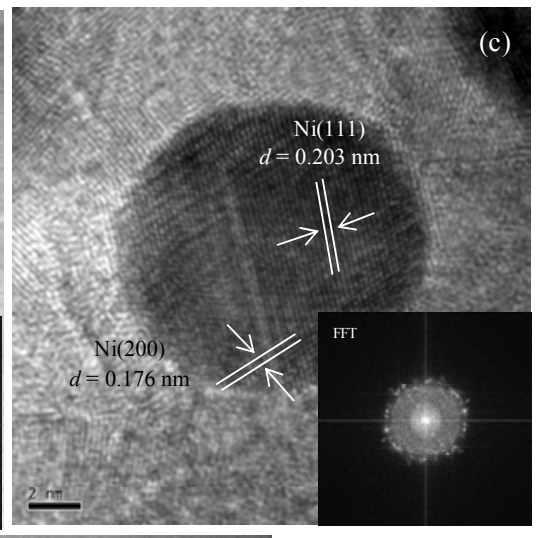

(e)

Fig. 3. HRTEM micrographs of catalysts after calcination and reduction. (a) TH-LDO; (b) LDO; (c) P3-LDO; (d) PP-LDO; (e) CB-LDO. 


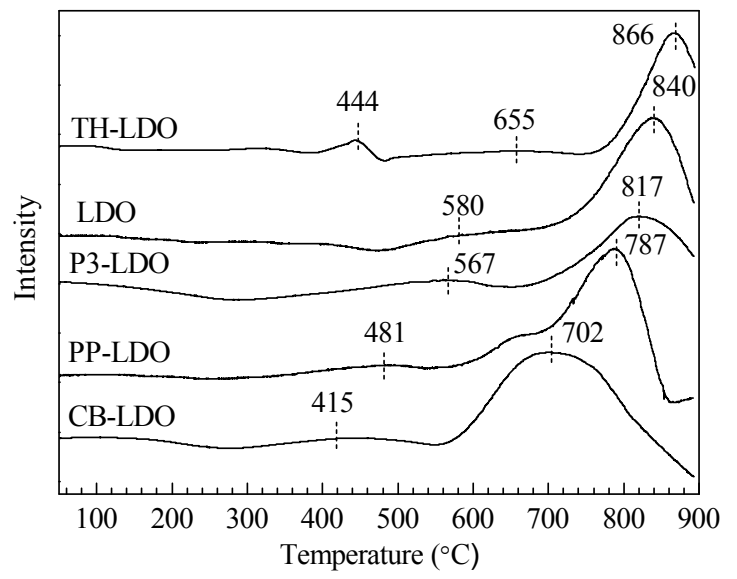

Fig. 4. $\mathrm{H}_{2}$-TPR profiles of catalysts after calcination.

connections between $\mathrm{Ni}$ particles and the support that are more compact and harder to reduce. SMSIs could also suppress sintering of $\mathrm{Ni}$ particles and carbon deposition on $\mathrm{Ni}$, and these effects help to achieve high catalytic activity and stability [26-28].

The XPS spectra of the catalysts after calcination and reduction are shown in Fig. 5. The binding energy of the peak at $852.5 \mathrm{eV}$ is attributed to $\mathrm{Ni}^{0}$ [29], which is in accordance with the weak interaction between $\mathrm{Ni}^{2+}$ and $\mathrm{Al}_{2} \mathrm{O}_{3}$ or $\mathrm{MgO}$ in the $\mathrm{H}_{2}$-TPR results. The binding energies of the peaks at 855.4 and $857.3 \mathrm{eV}$ are attributed to $\mathrm{Ni}^{2+}$ and $\mathrm{Ni}^{3+}$, with a satellite peak from $\mathrm{Ni}^{2+} 2 p_{3 / 2}$ at $861.2 \mathrm{eV}[30,31]$. The presence of high binding energies of $\mathrm{Ni}^{2+}$ confirm the presence of $\mathrm{Ni}-\mathrm{Al}$ spinel [32]. $\mathrm{Ni}^{0}, \mathrm{Ni}^{2+}$, and $\mathrm{Ni}^{3+}$ species are present on the catalyst surfaces after calcination and reduction; this is in accordance with the
TPR results, which show that Ni species are not totally reduced at $800{ }^{\circ} \mathrm{C}$. No regular relationships are seen among the peak areas of $\mathrm{Ni}^{0}, \mathrm{Ni}^{2+}$, and $\mathrm{Ni}^{3+}$ in Figs. 4 and 5 ; this may be because of unavoidable oxidation of the samples before XPS was performed. However, it has been reported that $\mathrm{Ni}^{x+}(x=0,2,3)$ species may collaboratively promote the reaction [33].

TEM micrographs and histograms of the Ni particle size distribution on the catalysts after calcination and reduction are shown in Fig. 6. The particle sizes are smaller than those calculated from the XRD (Table 2); this is because no correction was applied for widening of the XRD peaks. The most probable particle sizes of TH-LDO, LDO, and P3-LDO are around $10 \mathrm{~nm}$, and the distribution widths are slightly different. The most probable particle sizes of PP-LDO and CB-LDO are 8 and $6 \mathrm{~nm}$, respectively. The distribution width of PP-LDO is the narrowest. The smaller Ni particle size and narrowest distribution width are probably caused by the strong coordination of PVP with metal ions and the compressibility of the $c$ value of hydrotalcite. Similar phenomena for CB-LDO are caused solely by the compressibility of the $c$ value of hydrotalcite (Table 1). The TPR results also support the conclusion that PP-LDO and CB-LDO have the smallest particle sizes (Fig. 4). The reduction peak temperatures of both samples are less than $800{ }^{\circ} \mathrm{C}$, indicating that the reduction peaks could not be entirely attributed to the reduction of $\mathrm{Ni}^{2+}$ in a $\mathrm{Ni}-\mathrm{Mg}$ solid solution or $\mathrm{Ni}-\mathrm{Al}$ spinel $[24,25]$; they could be ascribed to the reduction of highly dispersed $\mathrm{NiO}$ particles with weak interactions with $\mathrm{Al}_{2} \mathrm{O}_{3}$ or $\mathrm{MgO}$ $[22,23]$. A combination of these results and the catalytic performances suggests that the $\mathrm{NiO}$ particles mentioned above make no contribution to the initial catalytic activity.

Figure 7 shows the $\mathrm{N}_{2}$ adsorption-desorption isotherms and pore size distributions for the TH-LDO, LDO, and CB-LDO cata-

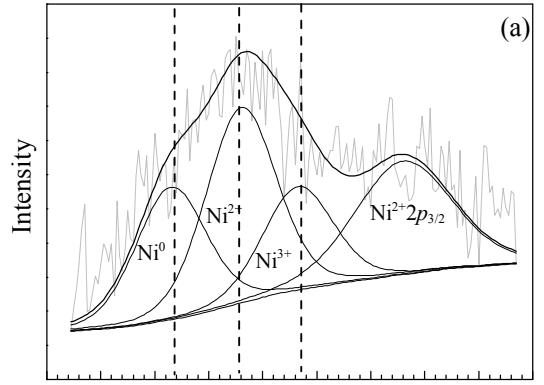

$848 \quad 850 \quad 852854856858 \quad 860862864866$ Binding energy $(\mathrm{eV})$

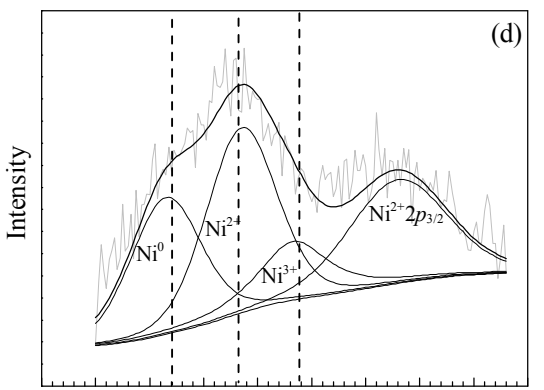

$848 \quad 850 \quad 852 \quad 854856858 \quad 860862864866$ Binding energy $(\mathrm{eV})$
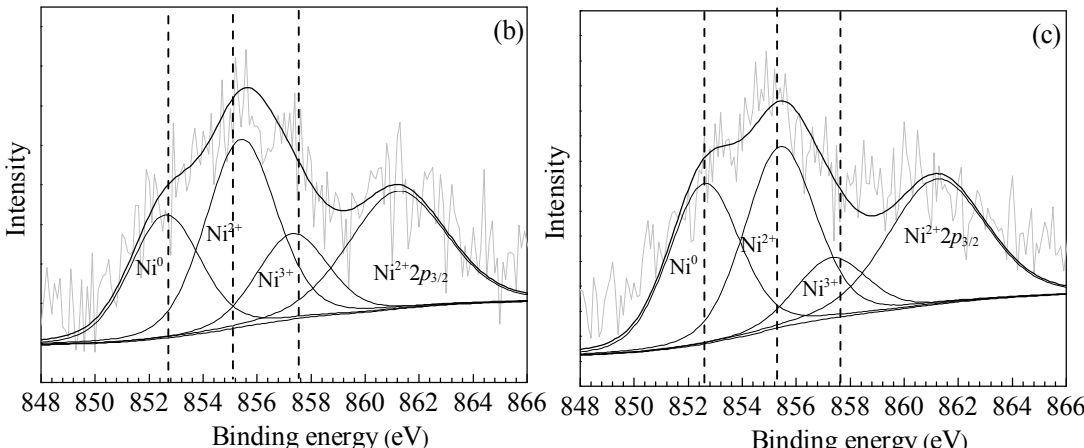
Binding energy $(\mathrm{eV})$

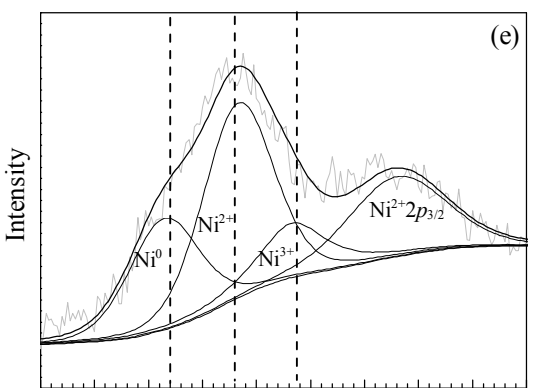

$848 \quad 850852854856858860862864866$

Binding energy $(\mathrm{eV})$

Fig. 5. XPS spectra of Ni $2 p_{3 / 2}$ band of catalysts after calcination and reduction. (a) TH-LDO; (b) LDO; (c) P3-LDO; (d) PP-LDO; (e) CB-LDO. 

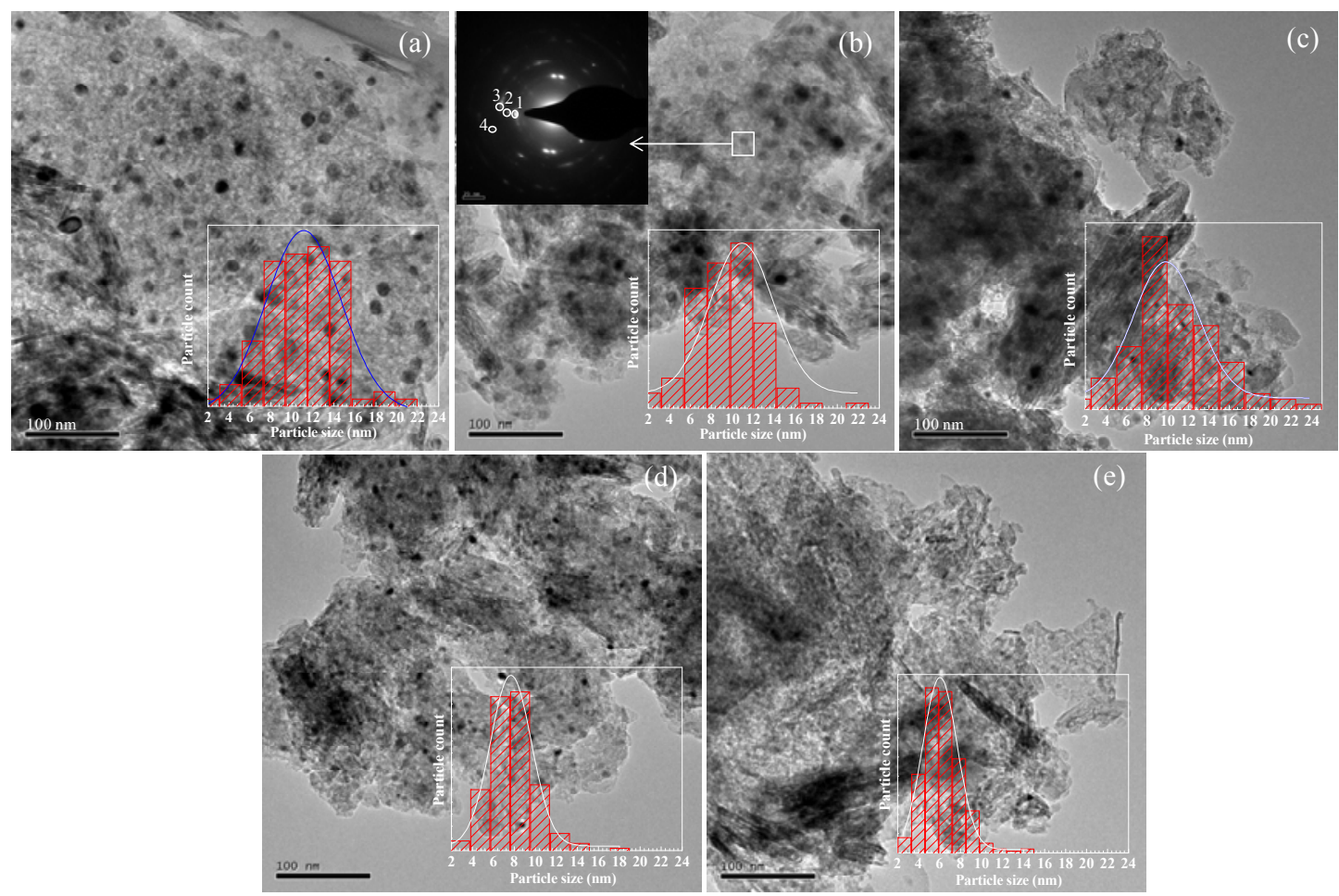

Fig. 6. TEM micrographs and histograms of Ni particle size distributions on catalysts after calcination and reduction; selected area diffraction pattern of the LDO catalyst. (a) TH-LDO; (b) LDO; (c) P3-LDO; (d) PP-LDO; (e) CB-LDO.

lyst samples after calcination. The TH-LDO, LDO, and CB-LDO catalysts have typical type IV isotherms with a hysteresis loop, and show a phase step at $p / p_{0}=0.5-0.6,0.7-0.8$, and $0.8-0.9$, respectively (Fig. 7(a)). The results show that all the samples are mesoporous materials. The TH-LDO and LDO catalysts have typical type IV isotherms with an $\mathrm{H} 1$ hysteresis loop. These $\mathrm{N}_{2}$ adsorption-desorption isotherms indicate that TH-LDO and LDO have highly ordered porous structures, and the mean pore diameters of the catalysts show highly localized distributions (Fig. 7(b)). The typical type IV isotherm with an H3 hysteresis loop of CB-LDO shows that it has large, diffuse slit-shaped pores, caused by accumulation of plate-like particles, causing aggregation or agglomeration of particles in solid CB-LDO $[34,35]$. Table 3 shows the $\mathrm{N}_{2}$ adsorption results for the TH-LDO, LDO, and CB-LDO catalysts. The result shows that

Table 2

Physicochemical properties of catalysts.

\begin{tabular}{lccc}
\hline Catalyst & \multicolumn{2}{c}{$\mathrm{Ni}^{0}$ crystal size $^{\mathrm{a}}(\mathrm{nm})$} & $\begin{array}{c}\text { Average carbon deposition } \\
\text { rate of used sample } \\
\left(\mathrm{mg}_{\mathrm{c}} /\left(\mathrm{h} \cdot \mathrm{g}_{\text {cat }}\right)\right.\end{array}$ \\
\cline { 2 - 3 } & Reduced & Used & 2.072 \\
TH-LDO & 14.5 & $14.0\left(800^{\circ} \mathrm{C}\right)$ & 4.329 \\
LDO & 13.5 & $13.0\left(800^{\circ} \mathrm{C}\right)$ & 5.461 \\
P3-LDO & 14.5 & $13.0\left(800^{\circ} \mathrm{C}\right)$ & 1.348 \\
PP-LDO & 15.0 & $13.0\left(800^{\circ} \mathrm{C}\right)$ & 1.679 \\
CB-LDO & unmeasured & $16.0\left(800^{\circ} \mathrm{C}\right)$ & 0.483 \\
& & $10.5\left(900^{\circ} \mathrm{C}\right)$ & 0.148 \\
\hline
\end{tabular}

a Calculated from XRD data of $\mathrm{Ni}(111)$ and $\mathrm{Ni}(200)$ with Scherrer equation.

${ }^{b}$ Calculated from the integral area of $\mathrm{O}_{2}$-TPO-MS curve line by using the software origin 8.0 (Charcoal activated power as the standard). there are significant differences among the textural properties of the catalysts before reaction, but after reaction, the textural properties of the catalysts are similar. These results are in agreement with those from the catalytic performance tests, i.e., the initial activities of all the catalysts are different, but after reaction, all the catalytic activities are similar. A comparison of the surface areas [TH-LDO $\left(251 \mathrm{~m}^{2} / \mathrm{g}\right)>$ LDO $\left(182 \mathrm{~m}^{2} / \mathrm{g}\right)>$ CB-LDO $\left.\left(106 \mathrm{~m}^{2} / \mathrm{g}\right)\right]$ and pore volumes indicates that a higher surface area and larger pore volume improve the $\mathrm{CH}_{4}-\mathrm{CO}_{2}$ reforming reaction, and surfactants significantly influence the textural properties of the catalysts.

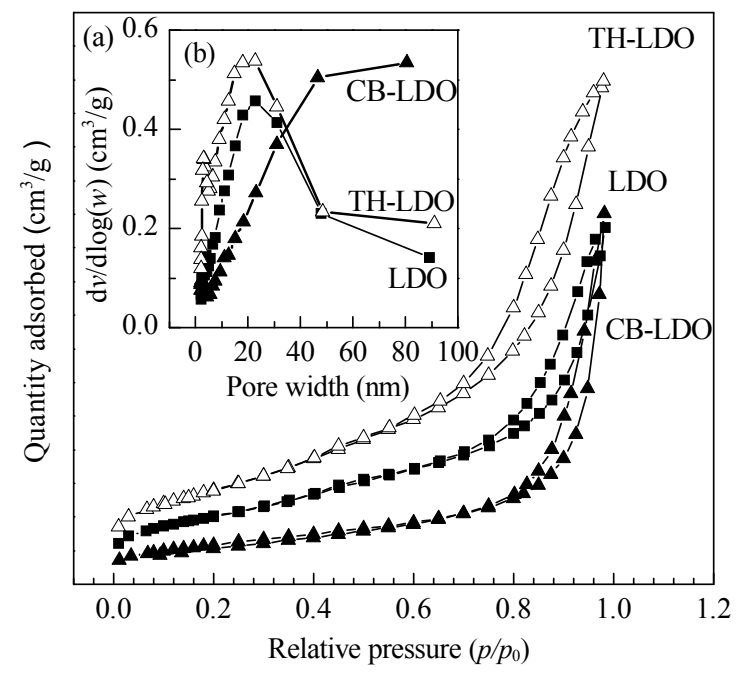

Fig. 7. $\mathrm{N}_{2}$ adsorption-desorption isotherms (a) and pore size distributions (b) of catalysts after calcination. 
Table 3

Textural properties of calcined and used $\left(800^{\circ} \mathrm{C}\right)$ catalysts.

\begin{tabular}{|c|c|c|c|c|c|c|}
\hline \multirow[t]{2}{*}{ Catalyst } & \multicolumn{2}{|c|}{$\begin{array}{c}\text { BET surface area } \\
\left(\mathrm{m}^{2} / \mathrm{g}\right)\end{array}$} & \multicolumn{2}{|c|}{ Pore size $(\mathrm{nm})$} & \multicolumn{2}{|c|}{$\begin{array}{c}\text { Pore volume } \\
\left(\mathrm{cm}^{3} / \mathrm{g}\right)\end{array}$} \\
\hline & Calcined & Used & Calcined & Used & Calcined & Used \\
\hline TH-LDO & 251 & 140 & 8.11 & 10.43 & 0.58 & 0.40 \\
\hline LDO & 182 & 145 & 8.79 & 10.15 & 0.41 & 0.37 \\
\hline CB-LDO & 106 & 135 & 14.50 & 11.21 & 0.38 & 0.43 \\
\hline
\end{tabular}

\subsection{Evaluation of catalyst stability}

The catalytic activities and stabilities of the Ni-Mg-Al-LDO catalysts are shown in Fig. 1. Experiments showed that the times on stream before $\mathrm{CH}_{4}$ conversion decreased to $48 \%$ were $35 \mathrm{~h}$ for TH-LDO, $32 \mathrm{~h}$ for LDO, and $26 \mathrm{~h}$ for CB-LDO. CB-LDO showed an initial induction period of $4 \mathrm{~h}$, during which no catalytic activity was detected. However, when the reaction time reached $10 \mathrm{~h}$, the activity quickly increased to a maximum, and remained stable for $4 \mathrm{~h}$, before deactivation. The results show that the deactivation times are different, but the deactivation rates are similar, for all the samples. This suggests that catalyst deactivation is mainly caused by external rather than intrinsic factors. To inhibit catalyst deactivation, it is necessary to investigate the real cause of the deactivation. The existence of an induction period for CB-LDO may be caused by encapsulation of fine particles of $\mathrm{Ni}$ species within the support, resulting in no active sites being available for $\mathrm{CH}_{4}$ cracking. The Ni particle size distributions and the blurred images in Fig. 6(e) confirm that $\mathrm{Ni}$ species were encapsulated within the support. The short induction periods also demonstrate that the pseudo-matrix formed can be quickly destroyed and reconstructed with the aid of heat from ion migration during the sustained high-temperature reaction. The active $\mathrm{Ni}$ species are then exposed and the catalytic reaction proceeds (Fig. 8). The effect of reaction temperature on the catalytic performance of CB-LDO was further investigated, to confirm our deduction.

Figure $9(\mathrm{a}-\mathrm{c})$ shows the results of evaluation of the catalytic activities and stabilities with time at 800,900 , and $1000{ }^{\circ} \mathrm{C}$ for CB-LDO. The results suggest that higher temperatures benefit $\mathrm{CO}_{2}$ reforming of $\mathrm{CH}_{4}$. However, the induction period cannot be eliminated, only shortened to a certain extent. Our preliminary deduction is that fine particles of $\mathrm{Ni}$ species were encapsulated within the support. A comparison of the XRD patterns of the reduced CB-LDO catalyst and the CB-LDO used at different temperatures (Fig. 9(d)) shows that there are no diffraction peaks for $\mathrm{Ni}^{0}$ or $\mathrm{Ni}(\mathrm{Mg}) \mathrm{Al}_{2} \mathrm{O}_{4}$ spinel from the reduced catalyst. In addition, no peak for crystalline $\mathrm{Ni}(\mathrm{Mg}) \mathrm{Al}_{2} \mathrm{O}_{4}$ spinel is detected in the catalyst used at $800{ }^{\circ} \mathrm{C}$. However, Ni(111),
$\mathrm{Ni}(200), \mathrm{Ni}(220)$, and $\mathrm{Ni}(\mathrm{Mg}) \mathrm{Al}_{2} \mathrm{O}_{4}$ spinel reflections [36,37] are detected for the catalysts used at 900 and $1000{ }^{\circ} \mathrm{C}$, indicating that formation of $\mathrm{Ni}(\mathrm{Mg}) \mathrm{Al}_{2} \mathrm{O}_{4}$ spinel causes exposure of the Ni (200) crystal plane. The order of the relative intensities of the $\mathrm{Ni}$ (200) reflections in the used catalysts [CB-LDO (35.6\%) $\left.1000{ }^{\circ} \mathrm{C}>\mathrm{CB}-\mathrm{LDO}(32.2 \%) 900{ }^{\circ} \mathrm{C}>\mathrm{CB}-\mathrm{LDO}(30.5 \%) 800{ }^{\circ} \mathrm{C}\right]$ further supports the proposal that that catalytic activity is related to $\mathrm{Ni}(200)$ exposure. The $\mathrm{Ni}(\mathrm{Mg}) \mathrm{Al}_{2} \mathrm{O}_{4}$ spinel formed in the reforming reaction at high temperature clearly enables slow release of $\mathrm{Ni}$ encapsulated within the support, and exposure of the $\mathrm{Ni}(200)$ plane stabilizes the catalytic activity under high-temperature conditions.

The XRD results show that the main catalyst phase before reaction is $\mathrm{NiO}-\mathrm{MgO}$ periclase with a cubic octahedral structure. According to the laws of thermodynamics, both the free energy and surface energy of a cubic octahedron are lower than those of a cube, therefore cubic octahedra have more stable states [38]. The study by Chen et al. [39] showed that spinel $\mathrm{NiAl}_{2} \mathrm{O}_{4}$ can significantly inhibit the formation of carbon deposits. In our experiments, the performance of the CB-LDO catalyst was better at $1000{ }^{\circ} \mathrm{C}$ than at 800 and $900{ }^{\circ} \mathrm{C}$. The same conclusion can be drawn from the phenomenon mentioned above. Clearly, a higher temperature improves the catalytic activity and stability. Theoretically, a higher temperature can accelerate the sintering of active metal particles and the formation of carbon deposits. However, a higher temperature can also enable reconstruction of the catalyst phase, which is useful. The data in Table 2 show that the average particle sizes of CB-LDO at 900 and $1000{ }^{\circ} \mathrm{C}$ are significantly smaller than that at $800{ }^{\circ} \mathrm{C}$. The conclusion that a higher temperature causes adverse changes therefore cannot be generalized.

To confirm the universality of the above conclusion, the best catalyst at $800{ }^{\circ} \mathrm{C}$, i.e., TH-LDO, was evaluated at $900{ }^{\circ} \mathrm{C}$ (Fig. 10). The results show that the initial $\mathrm{CH}_{4}$ conversion is almost the same at both temperatures. However, the catalytic activity at $900{ }^{\circ} \mathrm{C}$ decreases by about $10 \%$ compared with that at 800 ${ }^{\circ} \mathrm{C}$ at intermediate reaction times. Thereafter, the deactivation rate of TH-LDO at $900{ }^{\circ} \mathrm{C}$ is slower than that at $800{ }^{\circ} \mathrm{C}$. The deactivation rate of TH-LDO is different from that of the CB-LDO catalyst, but they are both deactivated slowly at higher temperatures.

\subsection{Analysis of catalyst deactivation}

In $\mathrm{CH}_{4}-\mathrm{CO}_{2}$ reforming, the deactivation of Ni-based catalysts is mainly caused by sintering of active metal particles, and coke formation on the catalyst surface [40-42]. Sintering promotes aggregation of $\mathrm{Ni}$ particles and increases their size. In this

\section{$\mathrm{Ni}$}

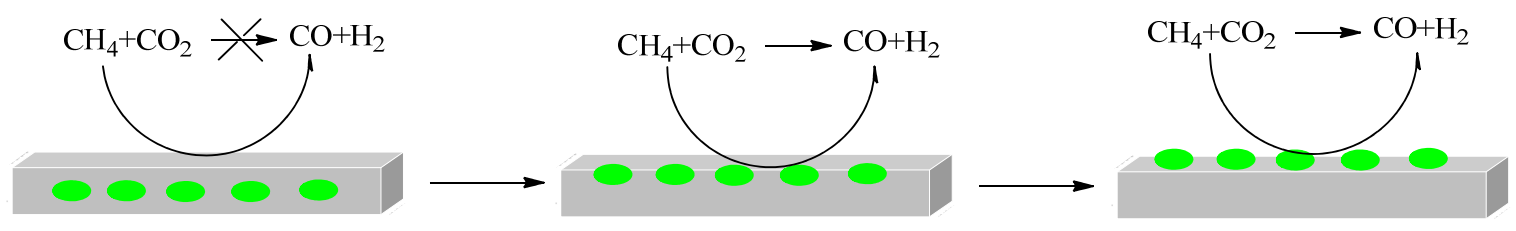

Fig. 8. Schematic diagram of release of active sites on Ni catalyst during $\mathrm{CH}_{4}-\mathrm{CO}_{2}$ reforming. 

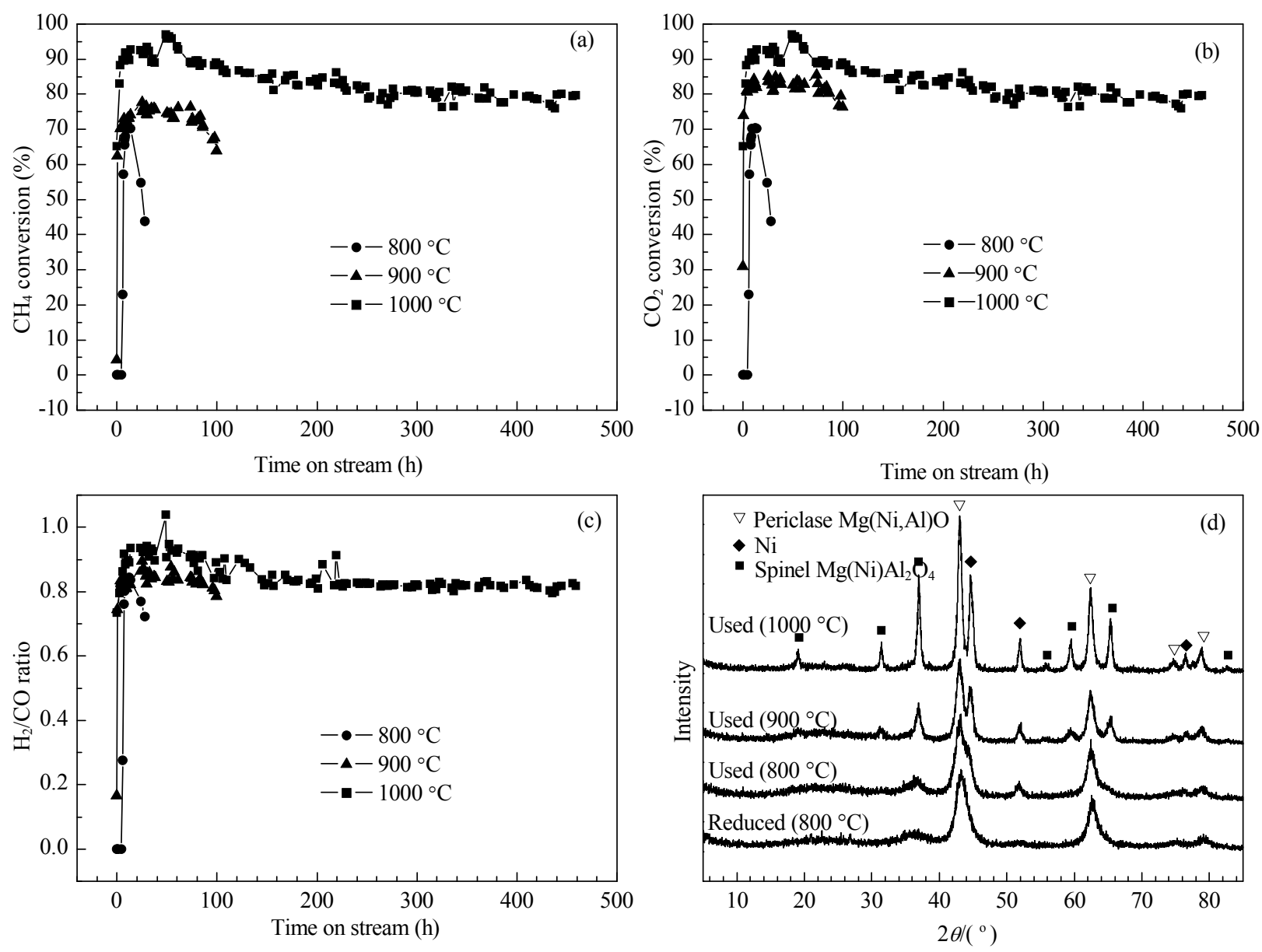

Fig. 9. $\mathrm{CH}_{4}$ (a) and $\mathrm{CO}_{2}$ (b) conversions and $\mathrm{H}_{2} / \mathrm{CO}$ product ratios (c) using CB-LDO catalyst with time on stream at various temperatures; (d) XRD patterns of CB-LDO catalyst. Reaction conditions: $\mathrm{CH}_{4} / \mathrm{CO}_{2}=1 / 1, p=0.1 \mathrm{MPa}, \mathrm{GHSV}=60000 \mathrm{~mL} /\left(\mathrm{h} \cdot \mathrm{g}_{\mathrm{cat}}\right)$.

study, the sizes of the $\mathrm{Ni}$ particles before and after reaction were almost the same, indicating that deactivation is mainly caused by carbon deposition, not catalyst sintering. The approximate deactivation rates of catalysts modified with different surfactants suggest that the growth rate of carbon deposits on the catalysts is determined by the properties of the coke and is not influenced by the catalyst characteristics. Coke formation

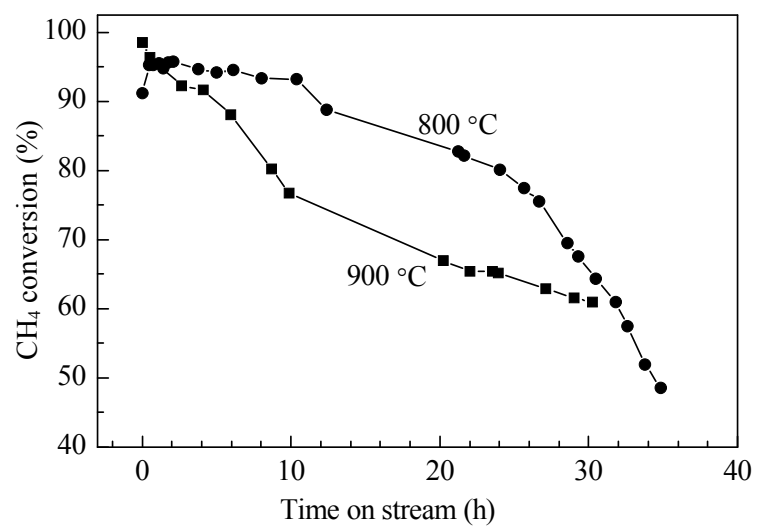

Fig. 10. $\mathrm{CH}_{4}$ conversions over LDO catalyst with time on stream at various temperatures. Reaction conditions: $\mathrm{CH}_{4} / \mathrm{CO}_{2}=1 / 1, p=0.1 \mathrm{MPa}$, $\mathrm{GHSV}=60000 \mathrm{~mL} /\left(\mathrm{h} \cdot \mathrm{g}_{\text {cat }}\right)$. should therefore be suppressed by the initial formation of coke.

The main source of carbon deposition in the $\mathrm{CH}_{4}-\mathrm{CO}_{2}$ reforming system is shown in reactions (1) and (2) [43-45]. It has been reported that there are three types of carbon deposited on catalysts after reaction, and they are classified based on the peak temperatures of the TPO-MS curves [25,46,47]: (1) atomic carbon $\left(\mathrm{C}_{\alpha}, T<250{ }^{\circ} \mathrm{C}\right),(2)$ amorphous carbon $\left(\mathrm{C}_{\beta}, 300\right.$ ${ }^{\circ} \mathrm{C}<T<500{ }^{\circ} \mathrm{C}$ ), and (3) graphitic carbon $\left(\mathrm{C}_{\gamma}, 600{ }^{\circ} \mathrm{C}<T<700\right.$ ${ }^{\circ} \mathrm{C}$ ). $\mathrm{C}_{\alpha}$ and $\mathrm{C}_{\beta}$ are oxidized above $300{ }^{\circ} \mathrm{C}$ and transformed into syngas in the reaction system. In contrast, $\mathrm{C}_{\gamma}$ is oxidized above $700{ }^{\circ} \mathrm{C}$, and it is hard to transform it into syngas [46,48,49]. The morphology of the carbon deposit is related to the graphitization degree, and the oxidizing temperature increases with increasing carbon crystallinity [49,50].

The $\mathrm{O}_{2}$-TPO-MS profiles of the catalysts after reaction at 800 ${ }^{\circ} \mathrm{C}$ are presented in Fig. 11(a). $\mathrm{CO}_{2}$ signals are observed from 330 to $750{ }^{\circ} \mathrm{C}$. It shows form Fig. 11(a) and Table 2 that the average carbon deposition rates of TH-LDO, LDO, and P3-LDO are high, especially for $\mathrm{C}_{\gamma}$, and the rates for PP-LDO and CB-LDO are low. These results are in accordance with the order of the most probable pore diameters of the Ni particles, obtained using TEM, and this also proves that carbon is more easily deposited on larger $\mathrm{Ni}$ particles $[51,52]$. In general, small $\mathrm{Ni}^{0}$ particles have high catalytic activity and can suppress carbon deposition, 

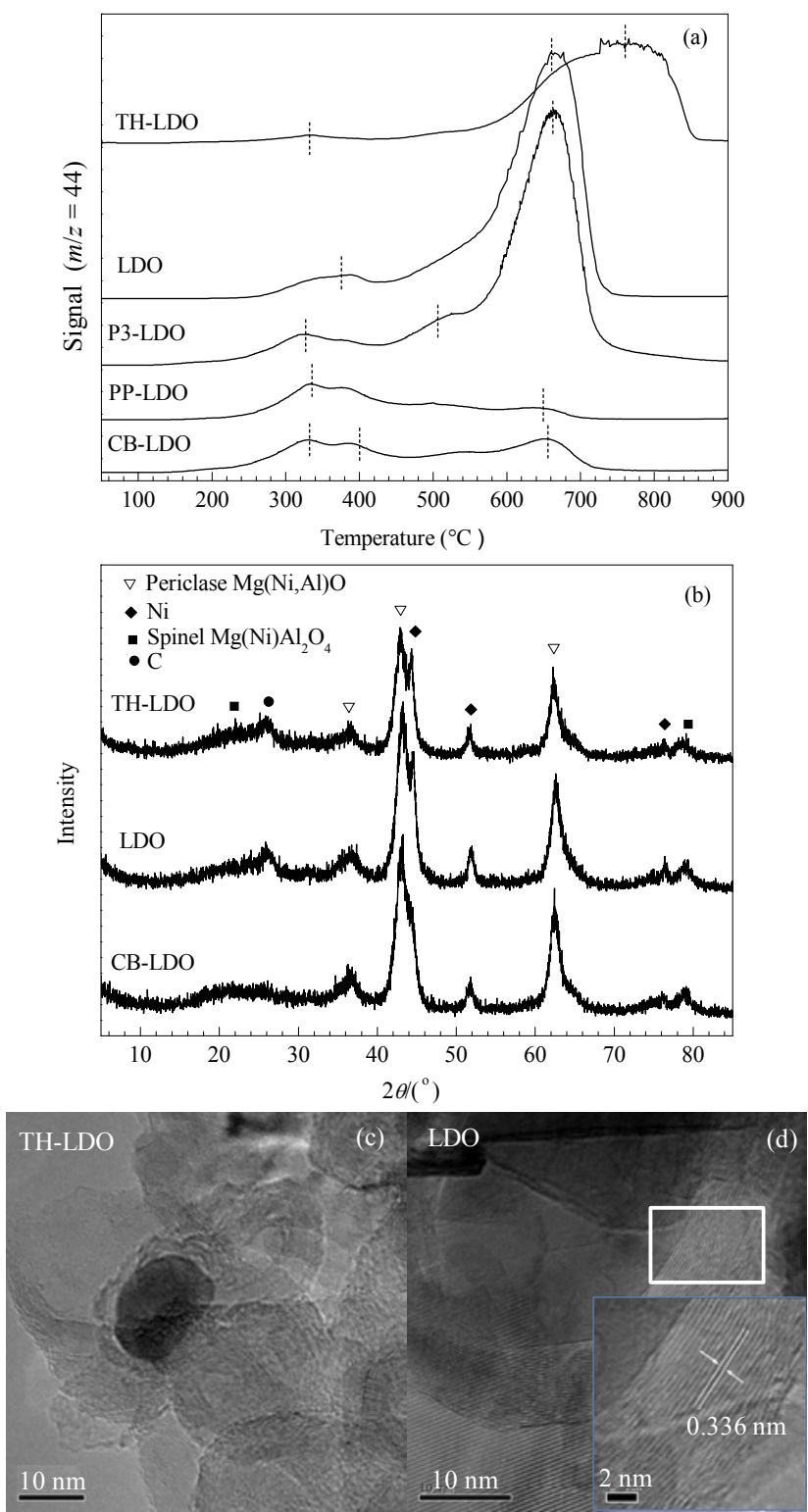

Fig. 11. $\mathrm{O}_{2}$-TPO-MS (a) and XRD patterns (b), and TEM micrographs (c, d) of catalysts at $800^{\circ} \mathrm{C}$ after stability tests.

and large $\mathrm{Ni}^{0}$ particles have low catalytic activity and carbon deposition is higher. The Ni particles in PP-LDO and CB-LDO are the smallest, and the average carbon deposition rates and initial activities of these catalysts are both very low. This indicates that the crystal orientation is also important in the catalytic activity.

The XRD patterns of the catalysts after reaction at $800{ }^{\circ} \mathrm{C}$ are shown in Fig. 11(b). There is a specific diffraction peak at $2 \theta=26^{\circ}$, which is attributable to graphitic carbon. Active metal encapsulation by carbon is observed in Fig. 11(c-d). The crystalline interplanar spacing of carbon is $0.336 \mathrm{~nm}$, measured from Fig. 11(d), which is similar to the value of $0.334 \mathrm{~nm}$ reported in the literature [53]. The clear lattice lines imply a high graphitization level of carbon, in accordance with the TPO-MS results.

The $\mathrm{O}_{2}$-TPO-MS profiles of CB-LDO after reaction at various temperatures are presented in Fig. 12(a). The amount of gra-
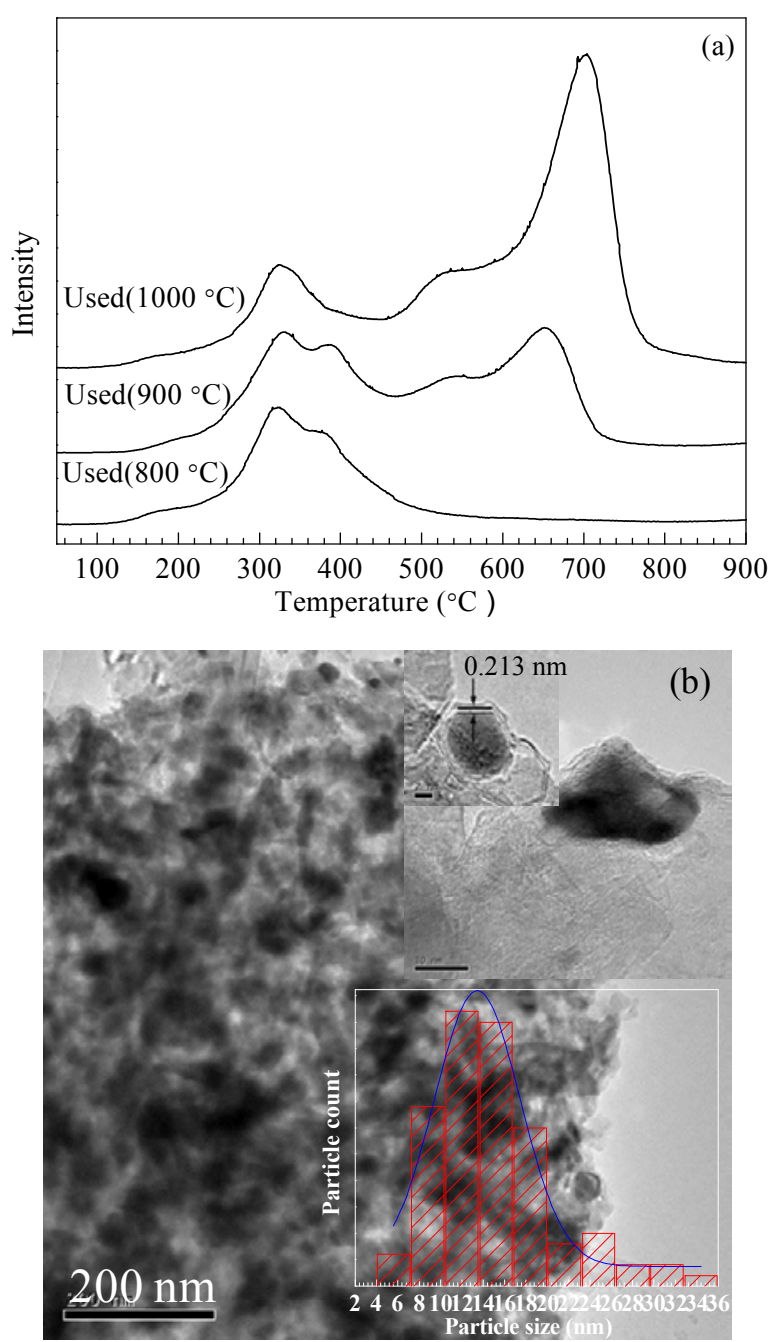

Fig. 12. (a) $\mathrm{O}_{2}$-TPO-MS profiles of CB-LDO after stability tests at various temperatures; (b) TEM micrographs of CB-LDO catalyst after reaction at $1000^{\circ} \mathrm{C}$.

phitic carbon increases with increasing reaction temperature. This is not specifically caused by the different reaction temperatures, because the reaction times for the three samples are also different: (1) $34 \mathrm{~h}$ for the sample reacted at $800^{\circ} \mathrm{C}$; (2) 100 $\mathrm{h}$ for the sample reacted at $900^{\circ} \mathrm{C}$; and (3) $456 \mathrm{~h}$ for the sample reacted at $1000{ }^{\circ} \mathrm{C}$. Their average carbon deposition rates are listed in Table 2. The average carbon deposition rate of the sample at $800{ }^{\circ} \mathrm{C}$ was the highest, $1.679 \mathrm{mg} /\left(\mathrm{h} \cdot \mathrm{g}_{\text {cat }}\right)$. The most probable particle size $(13 \mathrm{~nm})$ is close to the value $(12.5 \mathrm{~nm})$ calculated from the XRD patterns and is larger than the particle size after reduction $(6 \mathrm{~nm})$. This is the result of restructuring of catalyst species during the reaction. Ni encapsulation is also observed in the TEM micrograph; the lattice spacing is 0.213 $\mathrm{nm}$, which is different from the spacing of the graphitic carbon layers $(0.334 \mathrm{~nm})$ and similar to the lattice spacing $(0.211 \mathrm{~nm})$ of MgO(200) (JCPDS 450946), obtained from the XRD pattern. This suggests that $\mathrm{Ni}$ is encapsulated by $\mathrm{MgO}$ and is released during the reaction at higher temperature, which exposes active sites on $\mathrm{Ni}(200)$. The catalyst therefore shows excellent stability and activity in the reaction at higher temperature. 


\section{Conclusions}

In summary, the thickness, electron density, and laminar spacing of Ni-Mg-Al-LDHs precursors can be effectively regulated using a surfactant-assisted coprecipitation method. The physicochemical properties, microtextures, and crystal orientations of the fresh Ni-Mg-Al-LDO catalysts are affected by the surfactant. Different surfactants have different charge properties and various coordination abilities toward metal ions, and these influence the metal particle size and promote or restrain the growth of specific crystal planes. The catalytic performance depends not only on the Ni particle size, but is also affected by the relative degree of exposure of $\mathrm{Ni}(200)$. The reconstruction of catalyst species at high temperatures improves the catalytic activity, and this can be ascribed to controlled release of the $\mathrm{Ni}(200)$ crystal plane. This study demonstrates that carbon deposition is the main cause of deactivation of Ni-Mg-Al-LDO catalysts. Surfactants influence the initial generation of carbon to some extent. However, once carbon deposition starts, the carbon deposition rate is determined by the carbon type rather than the catalyst properties. The initial carbon deposition should therefore be suppressed, but the dynamic equilibrium point between carbon deposition and elimination needs to be established, and appropriate catalysts developed to solve the problem of carbon deposition.

\section{References}

[1] Naomohan, Fu X J, Lei Y Q, Zhang H J, Su H Q. Chin J Catal (瑙莫汗, 付晓娟, 雷艳秋, 苏海全. 催化学报), 2014, 34: 379
[2] Xu L L, Song H L, Chou L J. Appl Catal B, 2011, 108-109: 177

[3] Zhang X Q, Wang N, Xu Y, Yin Y X, Shang S Y. Catal Commun, 2014, 45: 11

[4] Shen C F. [MS Dissertation]. Tai yuan: Taiyuan Univ Technol (沈朝 峰. [硕士研究生学位论文]. 太原: 太原理工大学), 2013

[5] Forano C, Hibino T, Leroux F, Taviot-Guého C. Developments in Clay Science, 2006, 1: 1021

[6] Ren S B, Wen H Z, Cao X Z, Wang Z C, Lei Z P, Pan C X, Kang S G, Shui H F. Chin J Catal (任世彪, 文宏志, 曹先中, 王知彩, 雷智平, 潘春秀, 康士刚, 水恒福. 催化学报), 2014, 35: 546

[7] Xiang G L, Wang X. Chin J Inorg Chem (相国否, 王训. 无机化学学 报), 2011, 27: 2323

[8] Li Y, Shen W J. Sci Chin Chem, 2012, 55: 2485

[9] Hu Q H, Li X C, Yang A J, Yang C Y. Chin J Catal (胡全红, 黎先财, 杨 爱军, 杨春燕. 催化学报), 2012, 33: 563

[10] Rives V. Mater Chem Phys, 2002, 75: 19

[11] Gao P, Li F, Zhao N, Wang H, Wei W, Sun Y H. Acta Phys-Chim Sin (高鹏, 李枫, 赵宁, 王慧, 魏伟, 孙予罕. 物理化学学报), 2014, DOI: 10.3866/PKU.WHXB201401252

[12] Djebarri B, Gonzalez-Delacruz V M, Halliche D, Bachari K, Saadi A, Caballero A, Holgado J P, Cherifi O. Reac Kinet Mech Catal, 2014, 111: 259

[13] Zaghouane-Boudiaf H, Boutahala M, Arab L. Chem Eng J, 2012, 187: 142

[14] Li D L, Atake I, Shishido T, Oumi Y, Sano T, Takehira, K. J Catal, 2007, 250: 299

[15] Nam H S, Hwang N M, Yu B D,Yoon J K. Phys Rev Lett, 2002, 89: 275502

[16] Shen X J, Yang J P, Liu Y, Luo Y S, Fu S Y. New J Chem, 2011, 35: 1403

[17] Li P W, Wang N, Wang R M. Eur J Inorg Chem, 2010: 2261

[18] Li J D, Croiset E, Ricardez-Sandoval L. J Mol Catal A, 2012, 365:

\section{Graphical Abstract}

Chin. J. Catal., 2014, 35: 1955-1971 doi: 10.1016/S1872-2067(14)60171-6

$\mathrm{Ni}-\mathrm{Mg}$-Al solid basic layered double oxide catalysts prepared using surfactant-assisted coprecipitation method for $\mathrm{CO}_{2}$ reforming of $\mathrm{CH}_{4}$

Pengjia Tan, Zhihua Gao*, Chaofeng Shen, Yali Du, Xiaodong Li, Wei Huang* Taiyuan University of Technology; The Sixth Academy of China Aerospace Science \& Industry Corporation; Huadian Electric Power Research Institute
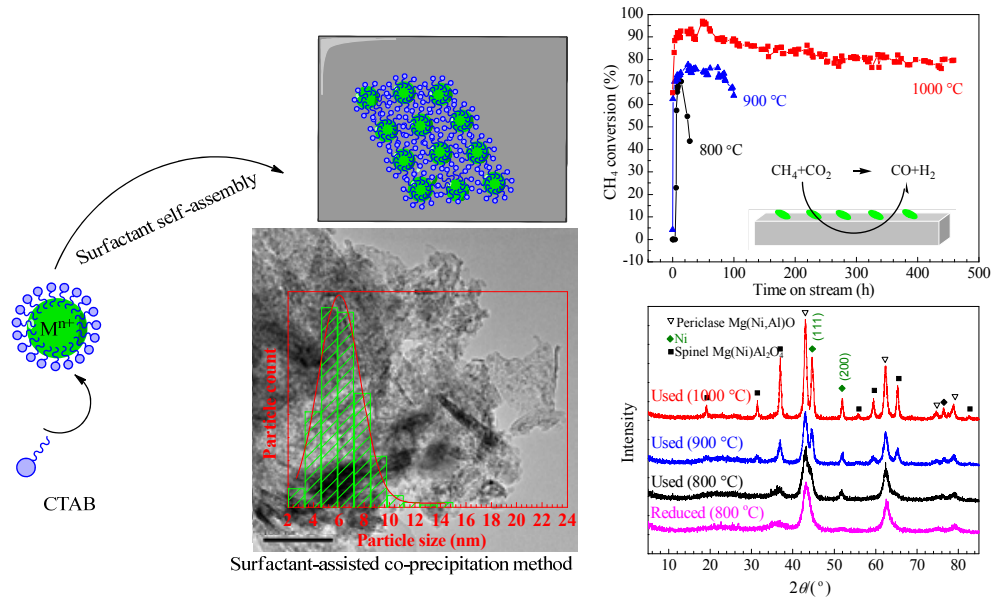

Highly dispersed $\mathrm{Ni}$ particles were encapsulated by cetyltrimethylammonium bromide. The $\mathrm{Ni}(200)$ plane was slowly released by $\mathrm{Ni}(\mathrm{Mg}) \mathrm{Al}_{2} \mathrm{O}_{4}$ spinel formation, giving excellent catalytic performances at high temperatures for $\mathrm{CO}_{2}$ reforming of $\mathrm{CH}_{4}$. 
103

[19] Wang S G, Cao D B, Li Y W, Wang J G, Jiao H J. Surf Sci, 2006, 600: 3226

[20] Wang Q S, Ren W, Yuan X L, Mu R M, Song, Z L,Wang X L. Int J Hydrogen Energy, 2012, 37: 11488

[21] Kumar P, Sun Y P, Idem R 0. Energy Fuels, 2008, 22: 3575

[22] Xiao H P, Liu Z C, Zhou X G, Zhu K K. Catal Commun, 2013, 34: 11

[23] Bang Y J, Han S J, Yoo J K, Choi J H, Kang K H, Song J H, Seo J G, Jung J C, Song I K. Int J Hydrogen Energy, 2013, 38: 8751.

[24] Dieuzeide M L, Iannibelli V, Jobbagy M, Amadeo N. Int J Hydrogen Energy, 2012, 37: 14926.

[25] Du X J, Zhang D S, Shi L Y, Gao R H, Zhang J P. Nanoscale, 2013, 5: 2659.

[26] Mora M, Jiménez-Sanchidrián C, Ruiz J R. J Colloid Interf Sci, 2006, 302: 568

[27] Lucrédio A F, Jerkiewickz G, Assaf E M. Appl Catal A, 2007, 333: 90

[28] Wang Z T, Shao X, Larcher A, Xie K, Dong D H, Li C Z. Catal Today, 2013, 216: 44

[29] Kang K M, Kim H W, Shim I W, Kwak H Y. Fuel Process Technol, 2011, 92: 1236

[30] Ning F Y, Shao M F, Zhang C L, Xu S M, Wei M, Duan X. Nano Energy, 2014, 7: 134

[31] Hou J, Liu Z M, Lin G D,Zhang H B. Int J Hydrogen Energy, 2014, 39: 1315

[32] Liu D P, Wang Y F, Shi D M, Jia X L, Wang X, Borgna A, Lau R, Yang Y H. Int J Hydrogen Energy, 2012, 37: 10135

[33] Damyanova S, Pawelec B. Arishtirova K, Fierro J L G. Int J Hydrogen Energy, 2012, 37: 15966

[34] Salam M A, Sufian S, Murugesan T. Mater Chem Phys, 2013, 142: 213
[35] Alvar E N, Rezaei M. Scripta Mater, 2009, 61: 212

[36] Hadian N, Rezaei M, Mosayebi Z, Meshkani F. J Nat Gas Chem, 2012, 21: 200

[37] Zhai X L, Ding S, Liu Z H, Jin Y, Cheng Y. Int J Hydrogen Energy, 2011, 36: 482

[38] Bai Y, Long R, Wang C M, Xiong Y J.J Univ Sci Technol Chin (柏战, 龙 手, 王成名, 熊宇杰. 中国科学技术大学学报), 2013, 43: 889

[39] Chen Y G, Ren J. Catal Lett, 1994, 29: 39.

[40] Liu C J, Ye J Y, Jiang J J, Pan Y X. ChemCatChem, 2011, 3: 529

[41] Zhu J Q, Peng X X, Yao L, Tong D M, Hu C W. Catal Sci Technol, 2012, 2: 529

[42] Wang N, Yu X P, Shen K, Chu W,Qian W Z. Int J Hydrogen Energy, 2013, 38: 9718

[43] Eltejaei H, Reza Bozorgzadeh H, Towfighi J, Reza Omidkhah M, Rezaei M, Zanganeh R, Zamaniyan A, Zarrin Ghalam A. Int J Hydrogen Energy, 2012, 37: 4107

[44] Koerts T, Van Santen R A. J Chem Soc, Chem Commun, 1991: 1281

[45] Shi C K, Zhang P. Appl Catal B, 2012, 115-116: 190

[46] Hao Z G, Zhu Q S, Jiang Z, Hou B L, Li H Z. Fuel Process Technol, 2009, 90: 113

[47] Zhang Z L, Verykios X E. Catal Today, 1994, 21: 589

[48] Zhang H, Li M, Xiao P, Liu D, Zou C J. Chem Eng Technol, 2013, 36:1701.

[49] Sun L Z, Tan Y S, Zhang Q D, Xie H J, Song F, Han Y Z. Int J Hydrogen Energy, 2013, 38: 1892

[50] Long J W, Laskoski M, Keller T M, Pettigrew K A, Zimmerman T N, Qadri S B, Peterson G W. Carbon, 2010, 48: 501

[51] Tang S, Ji L, Li J, Zeng H C, Tan K L, Li K. J Catal,2000, 194: 424

[52] Zhang J G, Wang H, Dalai Ajay K. Appl Catal A, 2008, 339: 121

[53] Kroll V C H, Swaan, H M, Mirodatos C. J Catal, 1996, 161: 409

\title{
表面活性剂辅助共沉淀法制备Ni-Mg-Al固体碱催化剂用于 $\mathrm{CH}_{4}-\mathrm{CO}_{2}$ 重整反应
}

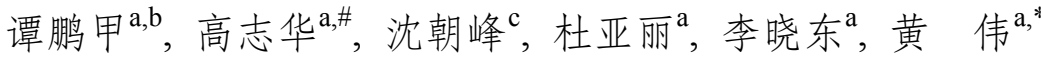 \\ a 太原理工大学煤科学与技术教育部和山西省重点实验室, 山西太原 030024 \\ ${ }^{b}$ 中国航天科工集团第六研究院389厂，内蒙古呼和浩特010010 \\ c 华电电力科学研究院, 浙江杭州 310027
}

摘要: 采用表面活性剂辅助共沉淀法制备了 Ni-Mg-Al固体碱催化剂并用于 $\mathrm{CH}_{4}-\mathrm{CO}_{2}$ 重整反应, 探讨了表面活性剂对 $\mathrm{Ni}(111)$, $\mathrm{Ni}(200)$ 晶面的择优取向作用, 在 $800^{\circ} \mathrm{C}$ 下比较了不同表面活性剂制备的催化剂的催化性能, 详细考察了 CTAB制备的催化剂 CB-LDO在不同反应温度下的催化活性和稳定性. 采用红外光谱、X射线衍射、程序升温还原、X射线光电子能谱、高分辨透射 电镜和程序升温氧化等表征手段分析了催化剂的活性、稳定性和失活原因. 结果表明, 四丙基氢氧化铵(TPAOH)促进 $\mathrm{Ni}(200)$ 的 生长, 而聚氧乙烯-聚氧丙烯-聚氧乙烯(P123)、聚乙烯吡咯烷酮(PVP)和十六烷基三甲基澳化铵(CTAB)抑制 Ni(200)晶面的生长; $\mathrm{Ni}(200)$ 的结晶程度对 $\mathrm{CH}_{4}$ 的活化起到关键的作用, 催化剂CB-LDO在高温下反应会发生晶型的转化, $\mathrm{Ni}(200)$ 晶面由于反应过程中 生成 $\mathrm{NiAl}_{2} \mathrm{O}_{4}$ 尖晶石而得到缓慢释放, 使催化剂的活性得以维持较高的水平.

关键词：表面活性剂; 共沉淀法; 镍; 镁铝氧化物;甲烷;二氧化碳；重整

收稿日期: 2014-04-27. 接受日期: 2014-07-01. 出版日期: 2014-12-20.

*通讯联系人. 电话/传真: (0351)6018073; 电子信箱: huangwei@tyut.edu.cn

\#通讯联系人. 电话/传真: (0351)6018466; 电子信箱: gaozhihua@tyut.edu.cn

基金来源：国家高技术研究发展计划(863计划, 2013AA051201).

本文的英文电子版由Elsevier出版社在ScienceDirect上出版(http://www.sciencedirect.com/science/journal/18722067).

\section{1. 前言}

$\mathrm{CH}_{4}$ 是天然气、煤层气、页岩气、沼气的主要成分,
在自然界中储量巨大; $\mathrm{CO}_{2}$ 是化石能源转化与利用中最 主要, 也是必然的排放物, 是炼钢高炉气、转炉气、窑炉 的主要成分. 将 $\mathrm{CH}_{4}$ 和 $\mathrm{CO}_{2}$ 进行重整制取合成气 $\left(\mathrm{CO}_{2}+\right.$ 
$\mathrm{CH}_{4} \rightarrow 2 \mathrm{CO}+2 \mathrm{H}_{2}, \Delta H^{\Theta}{ }_{298 \mathrm{~K}}=247 \mathrm{~kJ} / \mathrm{mol}$ )既可解决 $\mathrm{CH}_{4}$ 升值利用的问题, 也可实现 $\mathrm{CO}_{2}$ 减排. 当前, 国内外的许 多研究机构都致力于开发高活性和高稳定性的适合于 工业应用的 $\mathrm{CH}_{4}-\mathrm{CO}_{2}$ 重整催化剂. 原则上, 周期表中第 $\mathrm{VIII}$ 过渡金属和 $\mathrm{Ru}, \mathrm{Rh}, \mathrm{Pd}, \mathrm{Ir}$ 和Pt等贵金属都可以作为 $\mathrm{CH}_{4}-\mathrm{CO}_{2}$ 重整催化剂的活性组分. 然而, 事实上, 只有 $\mathrm{Ni}$ 和上述贵金属具有实际意义. 担载的贵金属是优良的重 整催化剂, 在高温下可使 $\mathrm{CH}_{4}$ 具有很高的转化率, 却不会 因为积炭而失活, 但由于价格昂贵, 其工业应用受到了 限制. $\mathrm{Ni}$ 基催化剂由于高活性和廉价易得 ${ }^{[1]}$, 被认为是 $\mathrm{CH}_{4}-\mathrm{CO}_{2}$ 重整最有前景的催化剂.

$\mathrm{Ni}-\mathrm{Mg}-\mathrm{Al}$ 水滑石是阴阳离子插层组装的一系列超 分子, 经过焙烧制得的固体碱催化剂(LDO)具有介孔结 构, 用于催化 $\mathrm{CH}_{4}-\mathrm{CO}_{2}$ 重整反应表现出优异的催化性能. $\mathrm{Xu}$ 等 ${ }^{[2]}$ 利用聚氧乙烯-聚氧丙烯-聚氧乙烯(P123)表面活 性剂作为软模板剂蒸发诱导组装制备了具有介孔结构 的Ni-Mg-Al(O)催化剂, 该催化剂比表面积高、孔体积较 大、孔径分布均匀, 用于 $\mathrm{CH}_{4}-\mathrm{CO}_{2}$ 重整反应在 $700{ }^{\circ} \mathrm{C}$, $\mathrm{GHSV}=15000 \mathrm{~mL} /\left(\mathrm{h} \cdot \mathrm{g}_{\mathrm{cat}}\right)$ 和 $\mathrm{CH}_{4} / \mathrm{CO}_{2}=1 / 1$ 的条件下, 反 应 $100 \mathrm{~h} \mathrm{CH}_{4}$ 的转化率仍保持在 $80 \%$. Zhang 等 ${ }^{[3]}$ 制备的 $\mathrm{Ni}-\mathrm{Mg}-\mathrm{Al}$ 水滑石催化剂在 $160 \mathrm{~h}$ 反应时间内没有观察到 失活. 本课题组 ${ }^{[4]}$ 前期以共沉淀法制备了 Ni-Mg-Al-LDO 催化剂, 在 $800{ }^{\circ} \mathrm{C} 、$ GHSV $=8000$ $\mathrm{mL} /\left(\mathrm{h} \cdot \mathrm{g}_{\mathrm{cat}}\right)$ 和 $\mathrm{CH}_{4} / \mathrm{CO}_{2}=1 / 1$ 的条件下, $2000 \mathrm{~h}$ 反应后 $\mathrm{CH}_{4}$ 和 $\mathrm{CO}_{2}$ 的转化率仍保持在 $95 \%$ 以上.

考虑到表面活性剂的引入可以调整水滑石的形貌、 颗粒大小等性质 ${ }^{[5]}$, 可以解决共沉淀法因沉淀剂的加入 使局部浓度过高产生团聚的弊端, 可以显著改善催化剂 中金属的分散度和织构性质 ${ }^{[6]}$ 、控制不同晶面暴露及制 备表面缺陷结构、实现对本征化学反应的调节 ${ }^{[7,8]}$ 和延缓 积炭等 ${ }^{[9]}$, 在前期研究的基础上, 本文采用表面活性剂辅 助共沉淀法制备Ni-Mg-Al-LDO催化剂, 考察了表面活 性剂对Ni-Mg-Al水滑石前驱体的微观作用以及进一步 对形成的复合氧化物的晶体结构、理化性质和 $\mathrm{Ni}$ 不同晶 面暴露的影响, 关联了催化剂结构和催化性能的关系.

\section{2. 实验部分}

\section{1. 催化剂制备}

Ni-Mg-Al固体碱催化剂采用表面活性剂辅助共沉 淀法制备. 将一定量的 $\mathrm{Na}_{2} \mathrm{CO}_{3}$ 溶于 $100 \mathrm{~mL}$ 去离子水, 表 面活性剂溶于 $50 \mathrm{~mL}$ 去离子水, 依次加入四口烧瓶. $60{ }^{\circ} \mathrm{C}$ 下同时将硝酸盐混合溶液 $((\mathrm{Ni}+\mathrm{Mg}) / \mathrm{Al}$ 的摩尔比为
3) $120 \mathrm{~mL}$ 和 $\mathrm{NaOH}$ 溶液 $(1 \mathrm{~mol} / \mathrm{L})$ 逐滴加入上述 $\mathrm{Na}_{2} \mathrm{CO}_{3}\left(n\left(\mathrm{CO}_{3}{ }^{2-}\right) / n\left(\mathrm{M}^{n+}\right)=2 / 3\right)$ 和表面活性剂的混合溶液 中, 强力搅拌保持 $\mathrm{pH}$ 值为 9.15 . 滴加完成后, 持续摚拌 3 $\mathrm{h}$, 将所得悬浊液转入晶化釜中于 $80^{\circ} \mathrm{C}$ 晶化 $24 \mathrm{~h}$. 晶化 完成后, 对悬浊液进行抽滤, 洗至 $\mathrm{pH}=7$. 滤饼在 $80^{\circ} \mathrm{C}$ 下干燥过夜, 再于 $700{ }^{\circ} \mathrm{C}$ (升温速率 $5^{\circ} \mathrm{C} / \mathrm{min}$ ) 恒温焙烧 6 $\mathrm{h}$, 焙烧之后的催化剂以-LDO命名, $\mathrm{NiO}$ 的质量分数为 $10 \%$. 未添加表面活性剂的催化剂命名为LDO, 添加表 面活性剂四丙基氢氧化铵(TPAOH)、P123、聚乙烯吡咯 烷酮(PVP)和十六烷基三甲基溴化铵(CTAB)的催化剂 依次命名为TH-LDO, P3-LDO, PP-LDO和CB-LDO.

\section{2. 催化剂表征}

催化剂前驱体的官能团鉴定采用Bruker Vertex70型 红外光谱仪测定, $\mathrm{KBr}$ 压片, 分辨率 $4 \mathrm{~cm}^{-1}$, 测量范围 $4000-400 \mathrm{~cm}^{-1}$.

催化剂织构使用Micromeritics ASAP 2020型吸附仪 测定, 采用BET和BJH公式计算催化剂的比表面积和平 均孔径.

晶相结构在DX-2700型X射线衍射(XRD)仪上用连 续扫描法测定 $\left(\mathrm{Cu} K_{\alpha}\right.$ 靶, $\left.\lambda=1.5405 \AA, 40 \mathrm{kV}, 30 \mathrm{~mA}\right)$; 扫 描范围 $2 \theta=5^{\circ}-85^{\circ}$, 扫描速率为 $8^{\circ} / \mathrm{min}$, 步长 $0.01^{\circ}$. 催化 剂的晶粒大小采用Scherrer方程求得.

活性金属的分散状态和形貌采用FEITECNAI $\mathrm{G}^{2} \mathrm{~F}-20$ 型高分辨透射电子显微镜(HRTEM)测定.

催化剂活性位 $\mathrm{Ni}$ 的化合价状态和电子结合能采用 Thermo Fisher公司Escalab 250型X光电子能谱(XPS)仪, 以单色化 $\mathrm{Al} K_{\alpha}(h v=1486.6 \mathrm{eV})$ 为 $\mathrm{X}$ 光源, 真空度优于 $2.0 \times 10^{-7} \mathrm{~Pa}$. 样品测试时, 通过能为 $30 \mathrm{eV}$, 步长 $0.1 \mathrm{eV}$. 采用污染碳 $\left(\mathrm{C} 1 s E_{\mathrm{b}}=284.6 \mathrm{eV}\right)$ 对样品进行荷电校正, 使用Sheirly法扣除背景.

催化剂的还原性质在TP-5000型(天津先权)程序升 温吸附仪进行. 将 $50 \mathrm{mg}$ 焙烧后催化剂装入石英管微型 反应器, 用纯 $\mathrm{He}$ 气在 $150{ }^{\circ} \mathrm{C}$ 下恒温吹扫 $30 \mathrm{~min}$, 降温至 $50{ }^{\circ} \mathrm{C}$ 后切换 $5 \% \mathrm{H}_{2} / \mathrm{N}_{2}$ 的混合气 $(20 \mathrm{ml} / \mathrm{min})$, 保持 $30 \mathrm{~min}$ 后从 $50{ }^{\circ} \mathrm{C}$ 升至 $900{ }^{\circ} \mathrm{C}\left(\right.$ 升温速率 $\left.10^{\circ} \mathrm{C} / \mathrm{min}\right)$ 进行程序升 温还原(TPR), 热导检测器检测耗氢量.

积炭的氧化性质测定在TP-5000型程序升温吸附仪 上进行. 将 $100 \mathrm{mg}$ 反应后催化剂装入石英管微型反应 器, 用纯 $\mathrm{He}$ 气在 $150{ }^{\circ} \mathrm{C}$ 下恒温吹扫 $30 \mathrm{~min}$, 降温至 $50^{\circ} \mathrm{C}$ 后切换 $5 \% \mathrm{O}_{2} / \mathrm{Ar}$ 的混合气 $(20 \mathrm{~mL} / \mathrm{min})$ 保持 $30 \mathrm{~min}$, 然后 从 $50{ }^{\circ} \mathrm{C}$ 升至 $900{ }^{\circ} \mathrm{C}$ 进行程序升温氧化(TPO)反应(升温 速率 $10^{\circ} \mathrm{C} / \mathrm{min}$ ). 尾气使用HIDEN (QIC-20)型质谱检测, 
绘制 $\mathrm{CO}_{2}$ 生成量与温度的关系曲线, 以此来判断碳物种 种类; 以活性炭氧化作为标准计算积炭含量.

\section{3. 催化剂评价}

催化剂活性评价在常压固定床(内径 $8 \mathrm{~mm}$ ) 反应装 置上进行, 将焙烧后催化剂 $0.30 \mathrm{~g}$ 与石英砂 $1.70 \mathrm{~g}(40-60$ 目)混和均匀放入石英管反应器内. 将石英管和热电偶 置于反应器保温炉中, 热电偶顶部感应部分插入反应炉 至反应管外壁, 紧贴催化剂床层. $800{ }^{\circ} \mathrm{C}$ 下用 $\mathrm{H}_{2} / \mathrm{N}_{2}$ $(\mathrm{V} / \mathrm{V}, 1 / 1)$ 预还原 $2 \mathrm{~h}$, 而后切换原料气 $\mathrm{CH}_{4} / \mathrm{CO}_{2}=1 / 1$, $\mathrm{GHSV}=60000 \mathrm{~mL} /\left(\mathrm{h} \cdot \mathrm{g}_{\mathrm{cat}}\right)$, 于不同温度下反应. 反应尾 气经冷凝除水后用上海海欣气相色谱仪(GC-950)检测 (TDX-01型填充柱, 热导检测器, Ar载气).

\section{3. 结果与讨论}

\section{1. 催化剂性能评价}

课题组前期以无表面活性剂辅助共沉淀法制备的 催化剂 $\mathrm{LDO}$, 在 $800^{\circ} \mathrm{C}, \mathrm{GHSV}=8000 \mathrm{~mL} /\left(\mathrm{h} \cdot \mathrm{g}_{\text {cat }}\right)$ 和 $\mathrm{CH}_{4} / \mathrm{CO}_{2}=1 / 1$ 的条件下已完成了 $2000 \mathrm{~h}$ 的稳定性考察, $\mathrm{CH}_{4}$ 和 $\mathrm{CO}_{2}$ 转化率始终保持在 $95 \%$ 以上 ${ }^{[4]}$. 本文为了缩短 评价时间、提高催化剂笁选速度, 采取了提高空速 $\left(\mathrm{GHSV}=60000 \mathrm{~mL} /\left(\mathrm{h} \cdot \mathrm{g}_{\mathrm{cat}}\right), \mathrm{CH}_{4} / \mathrm{CO}_{2}=1 / 1\right)$ 以加速催化 剂积炭失活的方法. 图1为催化剂活性评价结果. 可以 看出, 相对于未加表面活性剂的催化剂LDO, 添加表面 活性剂TPAOH有明显的促进作用, $\mathrm{CH}_{4}$ 和 $\mathrm{CO}_{2}$ 初始转化 率都在 $95 \%$ 以上, 而表面活性剂P $123, \mathrm{PVP}$ 和 CTAB表现 出一定的抑制作用. 值得注意的是, PP-LDO的 $\mathrm{CH}_{4}$ 初始 转化率只有 $18 \%$, 而 CB-LDO的 $\mathrm{CH}_{4}$ 初始转化率几乎为 0 , 但随着反应的开始数小时内迅速达到顶点. 可见, 不同 表面活性剂辅助合成的催化剂初活性差异很大, 揭示了 表面活性剂对新鲜催化剂结构和表面态的显著影响.

\section{2. 催化剂活性分析}

图2(a)是未焙烧样品的XRD谱. 图中显示, 所有样 品均出现了水滑石化合物的特征衍射峰, 对应于晶面 (003), (006), (009), (015), (018), (110)和(113), 没有发现 任何相关的氧化物或氢氧化物的特征峰, 表明制备的水 滑石化合物较纯. 图2(a)中, 决定水滑石晶体中层间距 的(003)晶面特征衍射峰强度高 ${ }^{[10]}$ 、对称性好、峰形尖锐, 且(110)和 (113) 晶面衍射峰清晰可辨, 表明合成的 $\mathrm{Ni}-\mathrm{Mg}-\mathrm{Al}$ 水滑石呈六方晶型结构并结晶良好. 这也表明 表面活性剂辅助共沉淀法可以制备结晶完美的 Ni-Mg-Al-LDHs. 表1是采用Scherrer方程计算的晶胞参 数 $a\left(a=2 d_{(003)}\right)$ 和 $c\left(c=d_{(003)}+2 d_{(006)}+3 d_{(009)}\right)$ 的值, 其中 $a$ 代表层板上金属盐离子的平均半径; 而 $c$ 值与层板厚 度、层板的电荷密度、层间阴离子的大小及层间水分子 数量密切相关 ${ }^{[11]}$. 由表1可知, 加入表面活性剂 $\mathrm{TPAOH}$, PVP和CTAB都使晶胞参数 $c$ 减小, 表明层板正电荷密度 增加, 层板与层间阴离子间的库仑作用力增强; 而加入 P123晶胞参数 $c$ 增大, 表明层板正电荷密度减小, 层板与 层间阴离子间的库仑作用力减弱. TPAOH, PVP, CTAB 的共同特点是都含有 $\mathrm{N}$ 原子, 其中 $\mathrm{TPAOH}$ 和 $\mathrm{CTAB}$ 是季 铵盐类化合物, PVP由于 $\mathrm{N}$ 与羰基相连, 使其 $\mathrm{N}$ 也具有缺 电子性, 这是它们能增强层板与层间阴离子间的库仑作 用力的原因. 而 $\mathrm{P} 123$ 为中性分子, 没有缺电子中心且 $\mathrm{O}$ 原子上具有孤对电子, 电子云密度较大, 因此导致层板 正电荷密度减小, 层板与层间阴离子间的库仑作用力减 弱. 结合图1可知, 总体上, 能增强层板与层间阴离子间 的库仑作用力的表面活性剂, 亦即具正电性的表面活性 剂对催化剂活性有利.

图2(b)是未焙烧样品水滑石前驱体的FT-IR谱, 其中 $3543 \mathrm{~cm}^{-1}$ 处的吸收归因于金属氢氧化物层间 $-\mathrm{OH}$ 的伸 缩振动引起, $2925 \mathrm{~cm}^{-1}$ 处的吸收归属为层间氢键与碳酸 盐之间第二种 $-\mathrm{OH}$ 的伸缩振动, $1120 \mathrm{~cm}^{-1}$ 红外吸收峰是 $\mathrm{C}-\mathrm{N}$ 单键伸缩振动 ${ }^{[12]}, 1370$ 和 $858 \mathrm{~cm}^{-1}$ 可分别为 $\mathrm{CO}_{3}{ }^{2-}$ 伸 缩振动和面外弯曲振动. $1637 \mathrm{~cm}^{-1}$ 的吸收是来自层间 水分子 $(\mathrm{H}-\mathrm{O}-\mathrm{H}$ 和 $\delta \mathrm{H}-\mathrm{O}-\mathrm{H})$ 的变形伸缩振动, 500-750 $\mathrm{cm}^{-1}$ 是来自 $\mathrm{M}-\mathrm{O}-\mathrm{M}$ 键 $(\mathrm{M}=\mathrm{Mg}, \mathrm{Ni}$ 和 $\mathrm{Al})$ 的伸缩振动 ${ }^{[13]}$, 属于水滑石骨架结构的特征峰，该峰的出现进一步证实 了产物是规整的水滑石化合物.

图2(c) 是Ni-Mg-Al-LDO催化剂经焙烧还原后样品 的XRD图. 图中 $2 \theta=36.4^{\circ}, 43.4^{\circ}, 62.9^{\circ}$ 和 $79.2^{\circ}$ 为方镁石 $\mathrm{Mg}(\mathrm{Ni}, \mathrm{Al}) \mathrm{O}$ 晶相的特征衍射峰 ${ }^{[14]} .2 \theta=44.5^{\circ}, 51.8^{\circ}$ 和 $76.3^{\circ}$ 分别对应于 $\mathrm{Ni}(111),(200),(220)$ 晶面的特征衍射. 由图2(c)可见 $\mathrm{Ni}(111)$ 和 $\mathrm{Ni}(200)$ 的结晶状态存在差异, 最 明显的是 $\mathrm{Ni}(200)$ 面从下到上逐次增加. 为避免不同次 测量带来的误差, 以 TH-LDO在 $2 \theta=44.5^{\circ}$ 处的肩峰为 $\mathrm{Ni}(111)$ 峰位置, 以该位置的高度为 $\mathrm{Ni}(111)$ 强度计量, 其 与 $51.8^{\circ}$ 峰高比用以表示样品中 $\mathrm{Ni}(200)$ 的份额. 计算得 $I_{\mathrm{Ni}(200)} / I_{\mathrm{Ni}(111)}$ 的顺序为: TH-LDO $(27.7 \%)>\mathrm{LDO}$ $(25.4 \%)>$ P3-LDO $(22.0 \%)>$ PP-LDO $(14.3 \%)>$ CB-LDO (11.1\%), 该顺序与催化剂初活性顺序相吻合, 暗示了 $\mathrm{Ni}(200)$ 对催化剂活性的意义. 各催化剂 $\mathrm{Ni}(200)$ 面暴露 程度不同的原因, 可归结为不同的表面活性剂在前驱体 形成时与不同晶面的作用能力不同, 不同的表面活性剂 会选择性地集中吸附在不同的晶面, 从而降低了该表面 
的自由能, 减缓该晶面的生长速度, 进而调控了金属粒 子的尺寸和形貌 ${ }^{[15]}$.

图3 是催化剂焙烧还原后的HRTEM图. 图3(a-d), 分别对应于催化剂样品 TH-LDO, LDO, P3-LDO 和 PP-LDO, 由图可以观察到明显的 $d$ 值为 0.203 和 $0.176 \mathrm{~nm}$ 的两个主要暴露晶面, 结合对应的傅里叶变换(FFT) 图 可以证实是 $\mathrm{Ni}(111)$ 和 $\mathrm{Ni}(200)$ 晶面, 与文献[16,17]的结果 一致。但在CB-LDO样品(图3(e)) 中没有发现 Ni(200)面 的存在. 这表明尽管前驱体在焙烧和还原处理后会发生 晶型变化及二次晶体生长, 但被表面活性剂保护的晶面 的生长仍会受到抑制.

金属 $\mathrm{Ni}$ 的晶体结构为面心立方 (fcc)结构, 按照fcc结 构的对称性, 它们的侧面是交替的 $\mathrm{Ni}(100)$ 和 $\mathrm{Ni}(111)$ 晶 面. $\mathrm{Ni}(200)$ 是晶胞结构中 $\mathrm{Ni}(100)$ 晶面的二级衍射, (200) 为干涉指数, (100) 是晶面指数, 虽然两者代表的含义不 同, 但在空间点群中的贡献相同, 所以XRD中Ni(200)可 以等同于空间点阵的 (100). 由于 $\mathrm{Ni}(111)$ 的平均 $\mathrm{d}$ 带中心 能量较高, 不利于 $\mathrm{CH}_{x}$ 的解离, 而 $\mathrm{Ni}(100)$ 可以通过降低 活化能垒促进 $\mathrm{CH}_{x}$ 物种的解离 ${ }^{[18]}$. 因此, 与 $\mathrm{Ni}(111)$ 相比, $\mathrm{Ni}(100)$ 亦即 $\mathrm{Ni}(200)$ 面是 $\mathrm{CH}_{4}$ 解离的首选表面 ${ }^{[19]}$, 这可以 解释前述 $\mathrm{Ni}(200)$ 相对强度与活性的顺变关系.

图4是焙烧后样品的 $\mathrm{H}_{2}$-TPR谱, 图中 $370-866^{\circ} \mathrm{C}$ 的 还原峰顶温度的差异表明 Ni-Mg-Al-LDO 中的 $\mathrm{NiO}$ 物种 与介孔骨架之间形成了不同的相互作用. 根据文献, $370-450{ }^{\circ} \mathrm{C}$ 的还原峰归属于纯 $\mathrm{NiO}$ 的还 原 ${ }^{[20,21]}$; $500-800{ }^{\circ} \mathrm{C}$ 的还原峰对应于 $\mathrm{Ni}^{2+}$ 和 $\mathrm{Al}_{2} \mathrm{O}_{3}$ 或 $\mathrm{MgO}$ 弱的相 互作用 ${ }^{[22,23]}$; 大于 $800{ }^{\circ} \mathrm{C}$ 的峰归属为 $\mathrm{Ni}-\mathrm{Mg}$ 固溶体中 $\mathrm{Ni}^{2+}$ 的还原或 $\mathrm{Ni}-\mathrm{Al}$ 尖晶石的还原 ${ }^{[24,25]}$. 其中高温还原峰 温度顺序为: TH-LDO $\left(866^{\circ} \mathrm{C}\right)>\operatorname{LDO}\left(840^{\circ} \mathrm{C}\right)>\mathrm{P} 3-$ $\operatorname{LDO}\left(817^{\circ} \mathrm{C}\right)>\operatorname{PP}-\operatorname{LDO}\left(787^{\circ} \mathrm{C}\right)>\mathrm{CB}-\mathrm{LDO}\left(702^{\circ} \mathrm{C}\right)$, 与 初活性顺序一致, 说明与载体作用强的 $\mathrm{Ni}$ 金属粒子是提 供催化活性位的主要位点. 文献报道 ${ }^{[26-28]}$, 金属与载体 的强相互作用(SMSI) 可以使金属 $\mathrm{Ni}$ 颗粒与载体结合的 更紧密, 分布更均匀, 不易还原, 同时可以抑制 $\mathrm{Ni}$ 颗粒的 烧结和积炭, 进而对催化剂活性和稳定性有利.

图 5 是催化剂焙烧还原后的XPS谱, 分别有 4 个结合 能位置. 结合能852.6 eV归属于 $\mathrm{Ni}^{0}{ }^{[29]}$, 对应于 $\mathrm{H}_{2}-\mathrm{TPR}$ 结 果中 $\mathrm{Ni}^{2+}$ 和 $\mathrm{Al}_{2} \mathrm{O}_{3}$ 或 $\mathrm{MgO}$ 弱的相互作用物种的还原; 结 合能855.4和857.3 eV可分别归属于 $\mathrm{Ni}^{2+}$ 和 $\mathrm{Ni}^{3+} ; 861.2 \mathrm{eV}$ 是 $\mathrm{Ni}^{2+} 2 p_{3 / 2}$ 的卫星峰 ${ }^{[30,31]}$; 高结合能 $\mathrm{Ni}^{2+}$ 的出现可作为 $\mathrm{Ni}-\mathrm{Al}$ 尖晶石存在的证据 ${ }^{[32]}$. 这表明焙烧还原后的催化 剂样品表面存在 $\mathrm{Ni}^{0}, \mathrm{Ni}^{2+}$ 和 $\mathrm{Ni}^{3+}$ 多种 $\mathrm{Ni}$ 物种, 与 TPR结果
一致, 即在 $800{ }^{\circ} \mathrm{C}$ 的预还原温度下氧化态 $\mathrm{Ni}$ 难以被完全 还原. 比较图 4 和图 5 可以发现, 归属于 $\mathrm{Ni}^{0}$ 和 $\mathrm{Ni}^{2+}, \mathrm{Ni}^{3+}$ 的 峰面积相对含量没有规律性的对应关系, 这可能是样品 在做XPS测试前转移过程中存在不可避免地被氧化的 结果. 然而不排除 $\mathrm{Ni}^{{ }^{x+}}(x=0,2,3)$ 间协同促进了反应的 进行 ${ }^{[33]}$.

图6是焙烧还原后催化剂的TEM图和Ni粒子尺寸分 布统计. 粒子分布统计整体上小于XRD中的计算结果 (见表2), 这是由于XRD测试时没有经过仪器宽化校正导 致. 比较各催化剂 $\mathrm{Ni}$ 粒子的尺寸分布可以发现, TH-LDO, LDO和P3-LDO最可几粒径相差不大, 均在 10 $\mathrm{nm}$ 左右, 只是分布宽度略有不同; PP-LDO最可几Ni粒 径约 $8 \mathrm{~nm}$, 而CB-LDO的约 $6 \mathrm{~nm}$, 前者分布宽度也是最窄 的. PP-LDO催化剂Ni粒径小、分布窄可能源于PVP分子 较强的与金属的配位能力以及对水滑石 $c$ 值的压缩能力, 而CB-LDO相同的现象则完全源于对水滑石 $c$ 值的压缩 能力 ( $c$ 值最小, 见表1). PP-LDO和CB-LDO的Ni粒径最 小也得到TPR实验的支持(图4): 二者的主还原峰顶温度 均不超过 $800{ }^{\circ} \mathrm{C}$, 因此不能完全归属于 $\mathrm{Ni}-\mathrm{Mg}$ 固溶体中 $\mathrm{Ni}^{2+}$ 的还原或 $\mathrm{Ni}-\mathrm{Al}$ 尖晶石的还原 ${ }^{[24,25]}$, 而应归属于高分 散的、与 $\mathrm{Al}_{2} \mathrm{O}_{3}$ 或 $\mathrm{MgO}$ 弱的相互作用 ${ }^{[22,23]}$ 的 $\mathrm{Ni}$ 氧化物粒 子还原. 关联催化剂性能评价可以推断, 与 $\mathrm{Al}_{2} \mathrm{O}_{3}$ 或 $\mathrm{MgO}$ 弱作用的Ni粒子对催化剂的初活性没有贡献.

选择具有代表性的 TH-LDO, LDO和CB-LDO催化 剂进行了织构性质的表征. 图7是焙烧后样品 $\mathrm{N}_{2}$-吸附脱附等温线及其孔径分布图. 可以看出, TH-LDO, LDO 和CB-LDO样品分别在相对压力 $p / p_{0}=0.5-0.6,0.7-0.8$ 和 $0.8-0.9$ 时存在阶跃, 并伴有滞后环, 属于典型的 IV 型 等温线, 表明其为典型的介孔材料. TH-LDO和LDO呈 现 H1 型滞后环, 说明孔结构规整有序且孔径分布集中 (见图7 (b)). 而CB-LDO呈现H3滞后环, 说明孔的类型主 要是由片状粒子堆积形成的狭缝孔, 而且对应的孔径较 大, 孔径弥散(见表3和图7 (b)), 表明CB-LDO固溶体中粒 子在形成狭缝孔时会发生聚集 ${ }^{[34,35]}$. 表3 为各催化剂样 品的织构性质. 可见, 反应前各样品的织构参数差别很 大, 但反应后大致趋于一致. 这与催化剂性能实验结果 吻合, 即初活性差异大, 反应结束时活性趋同. 比较反应 前各样品的比表面积和孔容: TH-LDO $\left(251 \mathrm{~m}^{2} / \mathrm{g}\right)>$ LDO $\left(182 \mathrm{~m}^{2} / \mathrm{g}\right)>$ CB-LDO $\left(106 \mathrm{~m}^{2} / \mathrm{g}\right)$, 表明比表面积和 孔容大的催化剂利于反应, 也说明表面活性剂对催化剂 的初始织构有明显的调控作用.

\section{3. 催化剂稳定性评价分析}


图1给出了 $800{ }^{\circ} \mathrm{C}$ 时各催化剂活性稳定性评价结果. 可见, 当 $\mathrm{CH}_{4}$ 转化率降至 $48 \%$, TH-LDO, LDO和CB-LDO 分别为 35,32 和 $26 \mathrm{~h}$. CB-LDO的明显特点是有一个活性 诱导期, 在反应前 $4 \mathrm{~h}$ 几乎没有活性, 之后至 $10 \mathrm{~h}$ 活性迅 速上升至最高值, 稳定 $4 \mathrm{~h}$ 后开始失活. 图 1还显示, 各催 化剂样品开始失活时间不同, 但失活速率大致相同(基 于图 $1 \mathrm{CH}_{4}$ 和 $\mathrm{CO}_{2}$ 转化率下降速度), 表明失活基本不受 催化剂自身性质影响, 而主要由其它因素决定. 因此, 抑 制失活应从探明失活的原因入手.

CB-LDO的活性诱导期可归结为部分细颗粒 $\mathrm{Ni}$ 物种 被载体包裹的结果, 正如图6(e)所示, Ni颗粒图像模糊不 清. $\mathrm{Ni}$ 被包覆以致无法提供 $\mathrm{CH}_{4}$ 解离的活性位. 短的诱 导期也表明随着持续的高温反应, 离子的热移动可迅速 打破基体物的噟形态, 进行重构, 进而使 $\mathrm{Ni}$ 活性物种得 以暴露, 使得催化反应得以进行(图8). 为证明这一推断, 本文又考察了反应温度对CB-LDO催化性能的影响.

图9(a-c) 是 CB-LDO在反应温度 800,900 和 $1000^{\circ} \mathrm{C}$ 下的评价结果. 可以看出, 提高反应温度可以显著提高 催化剂的活性和稳定性, 但未能导致诱导期消失, 只是 一定程度上缩短了诱导期, 初步证实了 CB-LDO中Ni的 物种被载体包裹的推断. 对比焙烧还原后和不同温度反 应后样品的XRD (图9(d)) 可以看出, 还原后的样品中没 有检测到 $\mathrm{Ni}$ 和尖晶石的特征衍射峰. $800^{\circ} \mathrm{C}$ 反应后也观 察不到尖晶石的特征衍射峰, 而 900 和 $1000^{\circ} \mathrm{C}$ 反应后样 品出现了明显的 $\mathrm{Ni}(111), \mathrm{Ni}(200), \mathrm{Ni}(220)$ 和尖晶石 $\left(\mathrm{MgAl}_{2} \mathrm{O}_{4}, \mathrm{NiAl}_{2} \mathrm{O}_{4}\right)$ 的特征衍射峰 ${ }^{[36,37]}$, 可以推测, 在重 整反应过程中生成 $(\mathrm{Ni}, \mathrm{Mg}) \mathrm{Al}_{2} \mathrm{O}_{4}$ 尖晶石是导致 $\mathrm{Ni}$ 活性 物种得以暴露的直接原因. 不同温度反应后样品的 $\mathrm{Ni}(200)$ 相对强度顺序 (CB-LDO(35.6\%)-1000 ${ }^{\circ} \mathrm{C}>$ CB-LDO (32.2\%)-900 $\left.{ }^{\circ} \mathrm{C}>\mathrm{CB}-\mathrm{LDO}(30.5 \%)-800^{\circ} \mathrm{C}\right)$ 进 一步支持了前述催化活性与 $\mathrm{Ni}(200)$ 暴露程度相关的论 断. 显然, 高温反应过程中不断形成 $\mathrm{NiAl}_{2} \mathrm{O}_{4}$ 尖晶石对被 载体包覆的 $\mathrm{Ni}$ 起到缓释作用, 逐渐暴露的 $\mathrm{Ni}(200)$ 晶面稳 定了高温反应下的催化剂活性.

催化剂反应前的主要物相是 $\mathrm{NiO}-\mathrm{MgO}$ 方镁石, 其晶 体结构为立方体型, 而尖晶石为含八面体的结构, 由于 立方八面体比立方体的表面积和表面自由能都低, 根据 热力学原理, 立方八面体呈现更稳定的状态 ${ }^{[38]}$. Chen 等 ${ }^{[39]}$ 报道尖晶石 $\mathrm{NiAl}_{2} \mathrm{O}_{4}$ 可以明显抑制 $\mathrm{CH}_{4}-\mathrm{CO}_{2}$ 重整中 的积炭, 与本文中 $\mathrm{CB}-\mathrm{LDO}$ 在 $1000{ }^{\circ} \mathrm{C}$ 反应性能优于 800 和 $900{ }^{\circ} \mathrm{C}$ 的结果一致. 显然, 对于某些特定的催化剂, 可 以通过提高反应温度来提高活性和延长寿命. 理论上,
高温反应会加速活性金属烧结和积炭, 但同时也会引起 催化剂物相重构, 从而导致有益的变化. 由表2中可清楚 地看到, CB-LDO在 900 和 $1000{ }^{\circ} \mathrm{C}$ 反应后的 $\mathrm{Ni}$ 粒子的平 均尺寸明显小于 $800{ }^{\circ} \mathrm{C}$ 下的 $\mathrm{Ni}$ 粒径. 因此, 高温反应必 然会导致不利的变化不能一概而论.

为了验证上述结论的通用性, 我们将 $800^{\circ} \mathrm{C}$ 反应表 现最优异的 TH-LDO催化剂在 $900{ }^{\circ} \mathrm{C}$ 进行评价, 结果见 图10. 可以看出, 在两个温度下反应的初活性相差无几, 然而, 反应中间段 $900{ }^{\circ} \mathrm{C}$ 反应的活性较 $800{ }^{\circ} \mathrm{C}$ 降低约 $10 \%$, 之后, 失活速率较 $800{ }^{\circ} \mathrm{C}$ 为慢, 这与 CB-LDO不尽 相同, 但高温下反应失活也较慢.

\section{4. 催化剂失活分析}

$\mathrm{CH}_{4}-\mathrm{CO}_{2}$ 重整过程中 $\mathrm{Ni}$ 基催化剂的失活主要是由于 活性金属的烧结和表面积炭 ${ }^{[40-42]}$. 烧结会促使Ni颗粒的 聚集, 进而使 $\mathrm{Ni}$ 颗粒长大. 本文中反应前(焙烧还原后) 和反应后的 $\mathrm{Ni}$ 颗粒大小变化不明显, 说明烧结不是催化 剂失活的主要原因, 失活是由积炭引起, 而不同表面活 性剂催化剂失活速率相近也表明积炭一旦形成, 其生长 速率将基本不受催化剂性质影响, 而是由积炭自身生长 特性决定. 因此, 抑制积炭生成应从抑制积炭的初始产 生入手.

$\mathrm{CH}_{4}-\mathrm{CO}_{2}$ 重整反应体系中, 反应式(1)和(2)是积炭的 主要来源 ${ }^{[43-45]}$. 研究表明 ${ }^{[25,46,47]}$, 反应后催化剂的 TPO-MS耗氧峰顶温度分布在 $<250{ }^{\circ} \mathrm{C}$ 为原子型碳 $\left(\mathrm{C}_{\alpha}\right)$, 300-500 ${ }^{\circ} \mathrm{C}$ 为无定型碳 $\left(\mathrm{C}_{\beta}\right), 600-700{ }^{\circ} \mathrm{C}$ 石墨状碳 $\left(\mathrm{C}_{\gamma}\right)$, 其中 $\mathrm{C}_{\alpha}$ 和 $\mathrm{C}_{\beta}$ 具有活性, 大于 $300{ }^{\circ} \mathrm{C}$ 就可以被氧化, 在反 应体系中可以转化为合成气, 而 $\mathrm{C}_{\gamma}$ 难以转化为合成气, 在 $700{ }^{\circ} \mathrm{C}$ 才能被氧化 ${ }^{[46,48,49]}$. 积炭的形貌反映了石墨化 结晶的程度, 氧化温度会随着碳结晶度的增加而升 高 ${ }^{[49,50]}$.

$$
\begin{gathered}
\mathrm{CH}_{4} \rightarrow \mathrm{C}(\mathrm{s})+\mathrm{H}_{2}, \Delta H^{\Theta}=75 \mathrm{~kJ} / \mathrm{mol} \\
2 \mathrm{CO} \rightarrow \mathrm{C}+\mathrm{CO}_{2}, \Delta H^{\Theta}=-172 \mathrm{~kJ} / \mathrm{mol}
\end{gathered}
$$

图 11(a) 是在 $800{ }^{\circ} \mathrm{C}$ 下应后的各催化剂 $\mathrm{O}_{2}$-TPO-MS曲线. 在 $330-750{ }^{\circ} \mathrm{C}$ 可以观察到明显的 $\mathrm{CO}_{2}$ 的信号. 由图11(a)和表2可见, TH-LDO, LDO和P3-LDO 的表面积炭率较高, 特别是 $\mathrm{C}_{\gamma}$; 而PP-LDO和CB-LDO积 炭速率较低. 这与TEM表征(图6)获得的最可几Ni粒度 大小顺序基本一致, 映证了在较大颗粒金属Ni粒子表面 容易产生积炭 ${ }^{[51,52]}$. 一般地讲, 小颗粒 $\mathrm{Ni}^{0}$ 具有高的催化 活性和抑制积炭性能, 大颗粒 $\mathrm{Ni}^{0}$ 活性低并易于生成积 炭. 本文中Ni粒径最小 (以 TEM统计结果为准)的催化剂 PP-LDO和CB-LDO积炭率都很低, 而初活性也不高, 这 
再次说明了除活性金属颗粒大小外, 对活性起至关重要 还有活性金属的晶面取向.

图11(b)是 $800^{\circ} \mathrm{C}$ 反应后催化剂的XRD图, $2 \theta=26^{\circ}$ 处出现了明显的石墨碳的特征衍射. 图11(c-d)的TEM 结果也表明活性金属被碳包覆. 从图11(d)测得的包覆 碳晶面间距为 $0.336 \mathrm{~nm}$, 与文献[53]报道 $0.334 \mathrm{~nm}$ 十分相 近, 并且晶格线清晰, 表明积炭的石墨化程度很高, 与 TPO-MS结果一致.

不同温度反应后CB-LDO样品的 $\mathrm{O}_{2}$-TPO-MS表征结 果见图12(a). 由图可以看出, 反应温度越高, 石墨型积 炭 $\left(\mathrm{C}_{\gamma}\right)$ 越多, 但这不能说明是温度引起的, 因为三个样品 的反应时间不同, 800,900 和 $1000{ }^{\circ} \mathrm{C}$ 样品分别反应了 34 , 100 和 $456 \mathrm{~h}$, 如果计算平均积炭速率的话, 后者只有 $0.148 \mathrm{mg}_{\mathrm{c}} /\left(\mathrm{h} \cdot \mathrm{g}_{\mathrm{cat}}\right)$, 而 $800{ }^{\circ} \mathrm{C}$ 样品高达 $1.679 \mathrm{mg}_{\mathrm{c}} /\left(\mathrm{h} \cdot \mathrm{g}_{\mathrm{cat}}\right)$ (见 表2).

图12(b) 是CB-LDO催化剂 $1000{ }^{\circ} \mathrm{C}$ 反应后粒子分布 统计和 TEM图, 其最可几粒径 $13 \mathrm{~nm}$, 与表 2 结果(12.5 $\mathrm{nm}$ ) 接近, 但是与还原时的 $6 \mathrm{~nm}$ 有长大的现象, 这是反应 过程中催化剂物相反生重构的结果. TEM图中 $\mathrm{Ni}$ 周围 可以清楚地观察到条纹间距为 $0.213 \mathrm{~nm}$ 的包覆物, 与石 墨碳层间距 $0.334 \mathrm{~nm}$ 相差很大, 但与XRD中方镁石结构 $\mathrm{MgO}$ (JCPDS 450946)的(200)晶面间距 $0.211 \mathrm{~nm}$ 相近, 暗
示着 $\mathrm{CB}-\mathrm{LDO}$ 中 $\mathrm{Ni}$ 被 $\mathrm{MgO}$ 包裹. 这部分 $\mathrm{Ni}$ 在高温反应过 程中由于相变化而得到了释放(图8), 暴露出了活性位 $\mathrm{Ni}(200)$ 面, 从而稳定了催化剂活性, 使CB-LDO在高温 反应时表现出较优异的性能.

\section{4. 结论}

采用表面活性剂辅助共沉淀法可以实现对 Ni-Mg-Al-LDHs前驱体层板厚度、层板电荷密度和层间 距的有效调控, 进而影响新鲜Ni-Mg-Al-LDO催化剂的 理化性质、微观织构以及晶体面取向; 表面活性剂通过 自身的电荷特性和与金属离子的配位能力, 影响催化剂 中金属粒子的大小以及促进或抑制 $\mathrm{Ni}$ 特定晶面的生长; 催化剂性能不仅取决于活性金属Ni粒度大小, 更取决于 $\mathrm{Ni}(200)$ 面暴露的相对比例; 高温下催化剂中物相的重 构会使某些催化剂性能得到改善, 其原因归结为物相重 构所带来的对 $\mathrm{Ni}(200)$ 晶面的缓释作用. 结果表明, 积炭 是导致Ni-Mg-Al-LDO催化剂的主要原因, 表面活性剂 可在一定程度上影响积炭的初始生成, 但一旦形成积炭 其生长速率将不主要受催化剂性质影响, 而是由积炭自 身生长特性决定. 因此, 抑制积炭生成应从抑制积炭的 初始产生入手; 同时, 建立积炭-消炭的动态平衡、开发 相应的催化剂才是根本. 